\begin{tabular}{|l|l|}
\hline 2. To: (Receiving organization) & 3. From: coriginating Organization) \\
Distribution & TWRS Equip. Engrg. \\
\hline 5. Proj./Prog./Dept./Div.: & 6. Design Authority/ Design Agent/Cog. \\
W-030 TWRS/TPCN NB604 & JR Kr.: Kriskovich \\
\hline
\end{tabular}

8. Originator Remarks:
FOR APPROVAL AND RELEASE OF A NEW SUPPORTING DOCUMENT.

11. Receiver Remarks: 11A. Design Basel ine Document? [X] Yes [] No
4. Related EDT No, :

$$
\mathrm{n} / \mathrm{a}
$$

7. Purchase Order No.:

$$
\mathrm{n} / \mathrm{a}
$$

9. Equip./Component No.:

$$
\mathrm{n} / \mathrm{a}
$$

10. System/Bldg./Facility: 241-AY/AZ

12. Major Assm. Dwg. No.: - H-2-13.1000, H-2-13.1075, \& $\mathrm{H}-2-131076$

13. Permit/Permit Application No.: $\mathrm{n} / \mathrm{a}$

14. Required Response Date: 13 February 1998

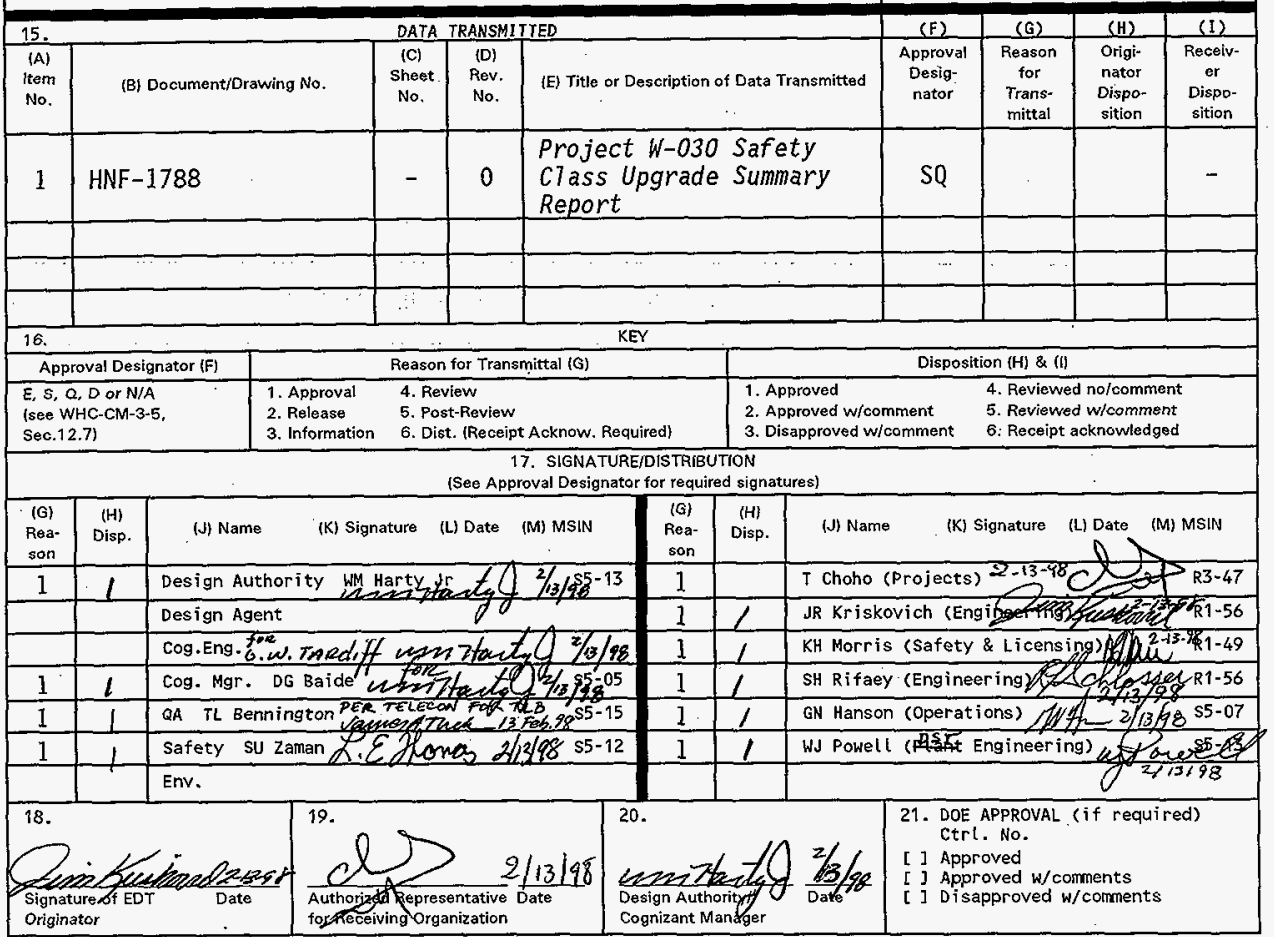


HNF-1788, Rev. 0

\section{Project W-030 Safety Class Upgrade Summary Report}

James R. Kriskovich

Lockheed Martin Hanford Corporation, Rich1and, WA 99352

U.S. Department of Energy Contract DE-AC09-96RL13200

EDT: 618224

Org Code: LM353000

B\&R Code: EW3130010

UC: 506

Charge Code: NB604

Tota1 Pages: 38

Key Words: ventilation, upgrades, primary confinement, safety class

Abstract: This document presents a summary of safety class criteria for the 241-AY/AZ Tank Farm primary ventilation system upgrade under Project $W-030$, and recommends acceptance of the system as constructed, based on a review of supporting documentation.

TRADEMARK DISCLAIMER. Reference herein to any specific commercial product, process, or service by trade name, trademark, manufacturer, or otherwise, does not necessarily constitute or imply its endorsement, recommendation, or favoring by the United States Government or any agency thereof or its contractors or subcontractors.

Printed in the United States of America. To obtain copies of this document, contact: WHC/BCS Document Control Services, P.0. Box 1970, Mailstop H6-08, Richland WA 99352, Phone (509) 372-2420;

Fax (509) 376-4989.
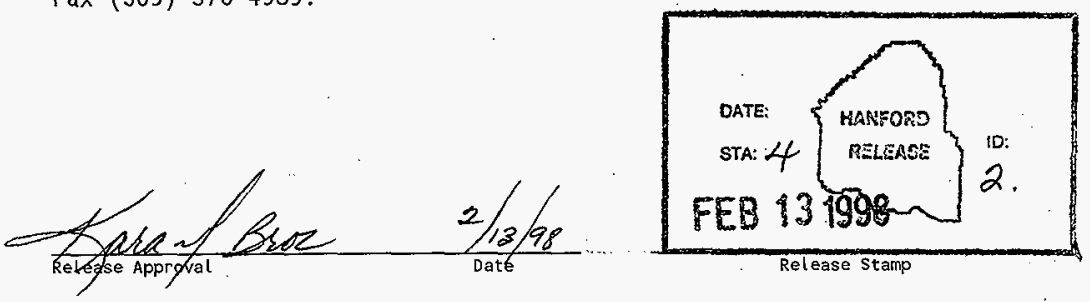

Approved for Public Release 


\section{PROJECT W-030 SAFETY CLASS UPGRADE SUMMARY REPORT}

HNF-1788 REV. 0 .

JIM KRISKOVICH

LOCKHEED MARTIN HANFORD CORPORATION

FEBRUARY 13, 1998 
1.0 INTRODUCTION $\ldots \ldots \ldots \ldots \ldots$

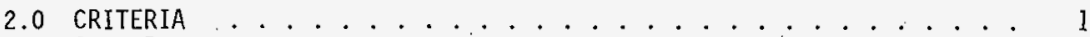

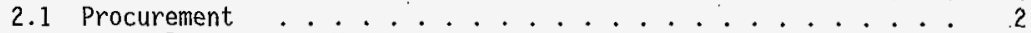

2.2 Natura Phenomena Hazards Mitigation ......... 3

2.3 Redundancy Requirements ............... 3

2.4 Electrical Power Requirements . . . . . . . . . . 3

3.0 DISCUSSION $\ldots \ldots \ldots \ldots \ldots \ldots$

3.1 Procurement .................. 4

3.2 Natural Phenomena Hazards Mitigation . . . . . . . . . 6

3.3 Redundancy Requirements ... . . . . . . . . . . 6

3.4 Electrical Power Requirements . . . . . . . . . . 6

4.0 RESULTS . . . . . . . . . . . . . . . . . . 7

4.1 Procurement . . . . . . . . . . . 7

4.2 Natural Phenomena Hazards Mitigation . . . . 8

4.3 Redundancy Requirement ... . . . . . . . . . . 9

4.4 ETectrical Power Requirements . . . . . . . . . . . . 10

5.0 CONCLUSION $\ldots \ldots \ldots \ldots$

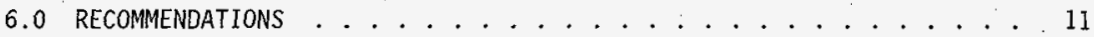

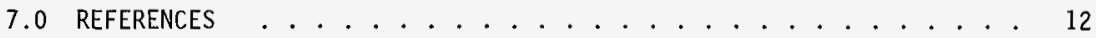

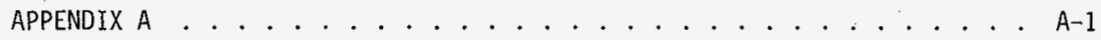

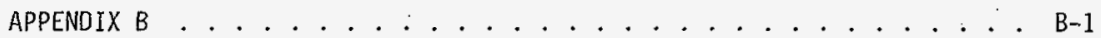


HNF-1788 Rev. 0

\section{PROJECT W-030 SAFETY CLASS UPGRADE SUMMARY REPORT}

\subsection{INTRODUCTION}

This report evaluates equipment design and procurement of the 241-AY/AZ Tank Farms Ventilation Upgrade Project $W-030$. The system and some components originally were classified and procured as Safety Significant (SS) (WHC, 1993). The Tank Waste Remediation System (TWRS) Basis for Interim Operation (BIO) (LMHC, 1997b) for all TWRS facilities, which became effective on September 29, 1997, now classifies active ventilation systems on Aging Waste Facilities as Safety Class (SC).

The U.S. Department of Energy, Richland Operations Office, has authorized the startup and operation of the Project $W-030$ ventilation system as a SS system as original7y designed (DOE-RL, 1997b) and identified in the prel iminary safety equipment 1 ist developed for the project (WHC, 1993). This is a temporary exemption, pending further evaluation and resolution of the discrepancies between the BIO and the original project design requirements for safety-related equipment. This document provides that evatuation.

It was demonstrated that the system met the original safety classification requirements to which Project $W-030$ was designed and built (Kriskovich, 1997a). As a minimum, this included various certifications, test results, design calculations, and other appropriate documentation demonstrating that the equipment met all the requirements for a SS system.

An evaluation was performed to determine what deficiencies exist in the design that may prevent it from meeting the safety classification requirements of SC based on the BIO (Kriskovich, 1997d). The deficiencies identified are as follows:

- Procurement of Safety Class Items

- Safety Class Natural Phenomena Criteria

- Safety Class Redundancy Requirements

- Safety Class Electrical Power Requirements.

The purpose of this report is to evaluate equipment design and procurement of Project $\mathrm{W}-030$ and recommend what measures, based on technical information, may be required to modify or dedicate the system to $S C$, and whether the benefits substantiate the added cost.

\subsection{CRITERIA}

Appendix A identifies the components of Project $W-030$ that will be designated as SC or SS. These safety structures, systems, and components (SSCS) are designated as SS or SC, based on the applicable facility safety 


\section{HNF-1788 Rev, 0}

analyses and safety classification criteria defined in a Hanford Site procedure (PHMC, 1997c).

Appendix $B$ contains a table of the components and an identification number and description listed for each component that were used to trace the specification that initiated the design and procurement of the item and any related vendor submittal or other documentation. The equipment was evaluated to determine if the design and procurement of a given item meets the requirements defined by the SC classification.

The original project design was based on the need for confinement to protect the onsite worker, corresponding to a SS classification. The BIO accidents relevant to ventilation are Flammable Gas Deflagrations and a within-structure Spray Leak (Section 5.3.2.14 and 5.3.2.20, LMHC, 1997b). According to this basis, the exhaust fans and any components supporting the safety function that provides flow are classified as SC. Included in this category are ductwork, piping, valves, supports, and electrical components whose failure could result in a loss of the safety function (flow). The continuous air monitor (CAM) interlock system is also classified as SC because of the spray leak accident scenario.

\subsection{Procurement}

A11 equipment for Project $W-030$ was classified and procured to either $S S$ or general service (GS) requirements.

Procurement requirements for safety SSCs are defined in a site procedure (PHMC, 1997b). This procedure does not distinguish between SS and SC to the extent of prescribing differing procurement requirements. Therefore, SSCs originally procured as SS also meet the requirements for SC and should be suitable for use in SC applications, provided that the items in question, by their design, satisfy al1 the other safety functions and requirements (i.e., natural phenomena). Such items do not require any upgrade other than documenting their acceptance. This report will satisfy the acceptance of those items. Procurement requirements for safety SSCS are:

- The equipment must be supplied by a qualified supplier, or testing/verification of material is required.

- The vendor must provide certification documents and appropriate design calculations or test results that demonstrate compliance with the procurement requisition or specification.

- For any commercial grade items (CGI), the critical characteristics must be identified and the method of dedication must be specified.

Some items originally classified and procured as GS now have a safety function because of the BIO accident analyses (see Section 3.0). Items procured as GS often 1 ack the documentation required to meet the current requirements for either SS or SC equipment, unless by a special dedication process or other means of upgrade (TWRS, 1997). If it is not possible to designate an item in this category as a safety SSC based on existing documentation, then the item would normally need to be modified, replaced, or 
bypassed by other equipment that can perform the necessary safety function to maintain the technical basis for operating the system.

\subsection{Natural Phenomena Hazards Mitigation}

Designing for natural phenomena loads is a requirement for Safety Class Structures Systems and Components as identified in DOE Order 6430.1A, Genera7 Design Criteria, (DOE, 1989). DOE Order $6430.1 \mathrm{~A}$ relies on 1 ocal or sitespecific criteria for the applicable factors used in the analyses. At the time design of Project $W-030$ was completed, the local or site-specific criteria were given in GC-Load-01, Design Loads for Facilities, (ICF KH, 1996). A7though GC-Load-01 was recently replaced by HNF-PRO-97, Engineering Design and Eva7uation (PHMC, 1997a) HNF-PRO-97 does not apply to this project because of the conceptual design date of Project W-030. HNF-PR0-97 only applies to design work initiated after October 15, 1997. As a resuit, this report will rely on the natural phenomena criteria identified in DOE Order 6430.1A and GC-Load-01.

Natural Phenomena for Safety Class SSCS consist of several different events. The SC events identified in DOE Order $6430.1 \mathrm{~A}$, and $\mathrm{GC}-[\mathrm{L}$ ad-01 are as follows:

Seismic loading $=0.2 \mathrm{~g}$ ground motion spectra

Wind Loading $=40 \mathrm{~m} / \mathrm{sec}(90 \mathrm{mph})$ basic wind speed

Tornado and Wind Missile $=50 \times 100 \mathrm{~mm}(2 \times 4)$ timber blank $7 \mathrm{~kg}$ (15 1b) (d) $22 \mathrm{~m} / \mathrm{sec}(50 \mathrm{mph})$

Volcanic Ash $=76 \mathrm{~mm}\left(3\right.$ inch) dry compacted ash o $1540 \mathrm{~kg} / \mathrm{m}^{\wedge^{3}}$ $\left(96 \mathrm{lb} / \mathrm{ft}^{\wedge 3}\right)$

Flooding $=40,800 \mathrm{~m}^{\wedge} / \mathrm{sec}\left(1 ; 440,000 \mathrm{ft}^{\wedge} / \mathrm{sec}\right)$

\subsection{Redundancy Requirements}

Redundancy and reliability are also $S C$ design requirements identified in DOE Order $6430.1 \mathrm{~A}$. The requirements are important factors in SC design because these attributes are crucial to assure the system and components are operational to achieve the safety function. Redundancy requirements apply to both electrical and mechanical systems. Redundancy is not required for SS applications; therefore, this report evaluates the necessity and adequacy for SC redundancy.

\subsection{Electrical Power Requirements}

As was the case for redundancy, electrical power is a key component to assure that the safety function of the system is met. The requirements differ, as identified in HNF-W030-TI-001 (Kriskovich, 1997d), between SS and SC. The primary difference between the two electrical power criteria is emergency power. For SS applications emergency power is not required; 
however, for SC applications it is required according to DOE Order 6430.1A. This report will evaluate whether it is necessary that emergency power be available to support the new ventilation system and if the adequacy of the original design is sufficient.

\subsection{DISCUSSION}

\subsection{Procurement}

Safety SSCs for Project $W-030$ were procured to SS requirements based on the origina1 Project $W-030 \mathrm{SEL}$ (WHC, 1993). Items requiring an upgrade from SS to SC constitute a majority of those tabulated in Appendix B. Since the same procurement requirements apply for both SS and SC (PHMC, 1997b), it is possible, where necessary, to upgrade the SS items to SC based on a review of existing vendor submittal and other project documentation against the safety functions and failure modes and effects in the BIO.

Most of the existing primary ventilation valves, or dampers, were procured based on structural integrity of the valve body as it forms part of the confinement boundary, with no safety function attributed to the valve operator. Based on the performance of the valve and Appendix $A$, these valves also contribute to the safety function of flow. In addition to maintaining their structural integrity, the valves in the primary flow path must not fail, in either a closed or open position under normal operating conditions, unless they are in a location where they can be bypassed. Otherwise, their faiture could lead to a loss of ventilation and accumulation of flammable gas in the tank. This failure mode is identified in Appendix $A$.

Several characteristics of these valves may be relied on for justifying their use, as procured, because of the additional failure mode and its effect on safety function. The valve operator is a simple mechanism that is inherently rugged and not prone to failure. The most common mode of failure is the inability to seat properly, as opposed to a major loss of function. This, combined with the relative ease of replacement, means that the valves are not a major concern in safety function and reliability, even when the additional criteria are considered. The original criteria of confinement, which ensured general integrity of the valve and valve body, can be relied on to provide the characteristics needed to support this safety application.

By design, most instrument loops depend on an interface through the Monitor and Control System (MCS) to perform their function. This interface is housed in the local control units (LCUS), those parts of the system which process and route various instrument signals and actually provide redundant, independent control of the ventilation system. The LCUS were procured SS and tested to withstand a SS seismic event as a procurement requirement. There are three instrument loops that currentiy interface with the MCS and LCUs that are safety related. The effects of losing the function of the LCUs and the safety-re]ated instrumentation they support are not considered because the system can operate manualiy without the MCS and LCUs. Therefore, this interface was not evaluated. 
The safety SSCS that interface with the LCU are the CAM interlock or primary high-efficency particulate air (HEPA) filter pressure differential switches (depending on which control is chosen) and the tank outlet air flow indicators and controllers. Either the CAM interlock or primary HEPA fiTter pressure differential will be classified as a Safety SSC to satisfy the technical safety requirement (TSR) (LMHC, 1997C) limiting control for operation for the spray leak accident scenario. For Project $W-030$, the CAM interlock was chosen.

For the CAM interlock, if the LCUs are lost, the stack monitor indication and alarm functions are designed to continue functioning independently of the LCU, but the fans must be shut down or switched manually in place of an automatic interlock function. Although this does not meet the requirements of Safety $\mathrm{Class}$ according to the BI0, design modifications are currently planned. The design modifications are part of the overall BIO implementation process to be completed before September, 1998. The modification will include an independently hardwired switch or other appropriate output function in parallel with the existing MCS software interface. In the meantime, since the alarm function is independent of. the LCU and MCS interface the current design is sufficient and acceptable.

For the air flow indicators and controllers, if the LCUs are lost the automatic flow control function, as well as remote flow indication are lost; however, local indication of flow is still available, satisfying the SC safety function. Also, tank pressure is being utilized to indicate flow through the tank. As for the function of controlling flow, the valves remain in position on loss of signal and can be manually adjusted. The air flow indicators and controllers therefore meet the SC criteria without further qualification.

The Standby (Diesel Powered) Electrical System was procured as SS engineered equipment. For further discussion see Section 3.4.

A review of vendor submittal for the remaining safety SSCs that were procured SS shows that they also meet the requirements for SC, because there is no change in functional requirements and the items meet all requirements for SC. These are identified as SC in Appendix B, where the relevant submittal are also referenced.

Other SSCs were procured GS. As shown in Appendix B, items originally procured as GS that are now classified as SS or SC are as follows:

- Buildings: Ventilation, Generator, and Recirculation Cooling Cell (SS).

- High Efficient Mist Eliminator (HEME) Radiation Monitoring Instrument Loop (SS):

- Normal Power Supply 500A, 400A, and 225A Main Breakers (SC).

- Primary ductwork and valving downstream of primary HEPA filters [downstream only; ductwork and valving upstream of filters was procured SS] (SC).

- Hangers and supports for SC ductwork or equipment (SC). 
Some of the above items may be upgraded by means of a dedication process; procedures HNF-PRO-447 (PHMC, 1997b) and HNF-PRO-0842 (LMHC, 1997a) define the requirements for this process. This approach will likely succeed with items for which ample documentation exists to verify the item can perform its safety function. The Ventilation, Generator, and Recirculation Buildings, HEME Radiation Monitor, and Normal Power Supply Breakers have sufficient documentation to warrant their use in SS or SC applications. Design. calculations, certificates of compliance (COCS), and other submittal which support this conclusion are referenced in Appendix B.

Other GS items are not sufficiently documented as to materials and testing, to be dedicated based on review of existing vendor submittal. Components in this category are the valves and piping (ductwork) downstream of the primary HEPA filters, including a crossover line and connections between the fans and filter trains, and the various SC pipe and equipment supports which were procured GS or fabricated from GS materials for Project $W-030$. Because these items were designated and procured as GS, they were supplied without certified material test reports (CMTRs) or COCs. Actions can be taken to utilize the material (Section 4.1).

\subsection{Natural Phenomena Hazards Mitigation}

The natural phenomena criteria identified in Section 2.2 was evaluated for Project $W-030$ (Kriskovich, 1997d) against the SC criteria. The evaluation relied on analyses that were already completed for Project $W-030$ for Safety Significant criteria. The evaluation consisted of scaling the original analysis to the Safety Class criteria.

\subsection{Redundancy Requirements}

In parallel with the natural phenomena evaluation, a reliability study was performed on the system (Braun, 1997) to assess the actual benefits, in increased reliability, for upgrading the deficient items to make the system compliant with SC requirements. The scope of the assessment compared the reliability of the old 702-A system and the new Project W-030 system configurations to operate over the course of a year with no external challenges. The assessment also estimates the reliability of a fully compliant Project $W-030$ system for seismic 10ading. The analys is was done for both SS and SC designations.

\subsection{Electrical Power Requirements}

A reliability study was also performed on the electrical power supply of the system (Kriskovich, 1997c). The scope of the study consisted of a reliability evaluation of the electrical power distribution system supplying the electric motor driven fans for the primary ventilation system. The study also included an investigation of the past history for the time taken to restore power. 


\subsection{RESULTS}

Results of the equipment evaluation are tabulated in Appendix B. An identification number and description are listed for each item of equipment, along with the specification used to procure the item, if applicable. Any equipment not listed is considered non-safety related, or GS.

\subsection{Procurement}

Two safety classifications are 1isted for each item in Appendix B. The "Required per BIO" column contains the classification of each SSC based on the safety function identified in the BIO, and as reflected in Appendix A. The "MEETS" column contains the present, minimum safety classification each item is judged to satisfy (SC, SS, or GS), based on the evaluation of procurement and design documentation against the criteria discussed in Section 2.0 above. (Kriskovich, 1997a). Supporting data are referenced in the "COMMENTS" column; submittal from vendors and contractors are retained with the corresponding specifications in the Project $W-030$ files.

Items not listed as meeting the required safety classification as identified in section 3.1 , based on a review of procurement submittal, are listed below in Table 4.1.1. In each case, the justification for using the item in a safety-related application, even though procured to a lower classification, is also summarized. For a more detailed discussion, see the previous section of this report. 
HNF-1788 Rev, 0

Table 4.1.1

\begin{tabular}{|c|c|c|}
\hline \multicolumn{3}{|c|}{ SUMMARY OF SC UPGRADE EVALUATION RESULTS } \\
\hline STRUCTURE OR COMPONENT & $\begin{array}{l}\text { CLASSIFICATION MET, BASED } \\
\text { ON PROCUREMENT }\end{array}$ & JUSTIFICATION FOR SC (OR SS) USE \\
\hline BUILDINGS & GS & $\begin{array}{l}\text { REQUIRED FOR SS APPLICATION; JUSTIFIED BASED ON } \\
\text { DESIGN TO SS LOADS, AS DOCUMENTED IN CALCULATIONS, } \\
\text { AS WELL AS COCS \& CMTRs. }\end{array}$ \\
\hline $\begin{array}{l}\text { PRIMARY SYSTEM VALVES/DAMPERS, } \\
\text { UPSTREAM OF HEPA FILTERS }\end{array}$ & SS & $\begin{array}{l}\text { REQUIRED FOR SC APPLICATION; JUSTIFIED BASED ON } \\
\text { INHERENT RUGGEDNESS OF VALVES, UNLIKELY MODE OF } \\
\text { FAILURE, AND EASE OF REPLACEMENT. }\end{array}$ \\
\hline $\begin{array}{l}\text { DUCTWORK AND VALVES } \\
\text { DOWNSTREAM OF HEPA FILTERS }\end{array}$ & GS & $\begin{array}{l}\text { REOUIRED FOR SC APPLICATION: JUSTIFIED BASED ON } \\
\text { INHERENT RUGGEDNESS OF VALVES AND PIPING, AS } \\
\text { VERIFIED BY PRESSURE BOUNDARY LEAK TEST, AND EASE } \\
\text { OF REPLACEMENT OF VALVES. }\end{array}$ \\
\hline SC EQUIP. SUPPORTS AND HANGERS & GS & $\begin{array}{l}\text { REQUIRED FOR SC APPLICATION; JUSTIFIED BASED ON } \\
\text { RELIABILITY STUDY OF SYSTEM (BRAUN, 1997), AND } \\
\text { DESIGN OR SELECTION TO MEET SS LOADS AS } \\
\text { DOCUMENTED IN AIE CALCULATIONS. }\end{array}$ \\
\hline CAM INTERLOCK & ss & $\begin{array}{l}\text { REQUIRED FOR SC APPLICATION, PER SEL; JUSTIFIED BASED } \\
\text { ON RELIABILITY STUDY OF SYSTEM (BRAUN, 1997), ACTION } \\
\text { STATEMENTS ADDRESSING FAILURE IN TSRS. }\end{array}$ \\
\hline PRIMARY HEPA DP FAN INTERLOCK & ss & $\begin{array}{l}\text { REQUIRED FOR SC APPLICATION, AS A COMPENSATORY } \\
\text { MEASURE; JUSTIFIED BASED ON RELIABILITY STUDY } \\
\text { (BRAUN, 1997) OF SYSTEM, \& ACTION STATEMENTS } \\
\text { ADDRESSING FAILURE IN TSRS. }\end{array}$ \\
\hline HEME RAD, MONITORING SYSTEM & GS & $\begin{array}{l}\text { REQUIRED FOR SS APPLICATION; JUSTIFIED BASED ON } \\
\text { VENDOR CERTIFICATION ANO CALIBRATION DATA. }\end{array}$ \\
\hline $\begin{array}{l}\text { NORMAL POWER SUPPLY MAIN } \\
\text { BREAKERS }\end{array}$ & GS & $\begin{array}{l}\text { REQUIRED FOR SC APPLICATION; JUSTIFIED BASED ON } \\
\text { RELIABILITY STUDY (KRISKOVICH, 1997C) OF ELECTRICAL } \\
\text { SUPPLY SYSTEM, AND CERTIFIED VENDOR CATALOG } \\
\text { INFORMATION. }\end{array}$ \\
\hline STANDBY (DIESEL) POWER SUPPLY & ss & $\begin{array}{l}\text { REQUIRED FOR SC APPLICATION; JUSTIFIED BASED ON } \\
\text { RELIABILITY STUDY (KRISKOVICH, } 1997 \text { ) OF ELECTRICAL } \\
\text { SUPPLY SYSTEM. }\end{array}$ \\
\hline
\end{tabular}

\subsection{Natural Phenomena Hazards Mitigation}

The evaluation completed (Kriskovich, 1997d) showed that all the natural phenomena criteria were met, via the scaling method, except for six items. Al] six of those items failed to meet the SC seismic criteria. The portions of the system that do not meet the seismic criteria are explained in detail in HNF-SD-W030-TI-001 (Kriskovich, 1997d) and as follows:

- Sections of the ductwork

- Ductwork and pipe supports

- Filter room raised floor structure

- Portions of the back-up generator building

- Equipment functionality after a seismic event 
- Toggle bolt anchorage for the cable trays.

Although the above components do not meet the criteria, the scaling method used is more conservative than other methods. For example, dynamic analysis is less conservative; therefore, if this were performed the above components may meet the criteria as is. However, the cost, and time to perform a dynamic analysis is significantly greater than the scaling method.

The maximum amount of over stress shown by the scaling was $22 \%$. This occurred in the toggle bolt anchorage for the cable trays. Therefore, the possibility exists that dynamic analysis may show that the components do meet the criteria.

The reliability study that was performed for Project W-030 (Braun, 1997) evaluated the increased reliability if the SC seismic criteria were met. Table 4.3.1 indicates there is a minor increase in the reliability of the system. It would be of 7ittle benefit to either perform a dynamic analysis, or replace the equipment in the field to meet the criteria.

Results of analyses of representative flammable gas deflagration scenarios are provided in BIO section 5.3.2.14. For the particular analyses reported in this section of the BIO, offsite REGs are exceeded for the Double Contained Receiver Tanks and Single Shell Tanks. Onsite REGs are ampiy exceeded for the particular analysis scenarios reported for the Double Shel1 Tanks and the Aging Waste Facility Tanks. As there is considerable technical uncertainty associated with Flammable Gas USQ, these particular representative accident scenarios are not deemed to be necessarily bounding or representative of true risk. At this stage of the process to close the USQ, the representative analysis serve to emphasize the importance of design features and operational controls which rigorously address the potential for flammable gas hazards. This is accomplished through the designation of SSCS as Safety Class and case by case consideration of the cost-benefit associated with upgrading existing Safety Significant SSCS. The benefit aspect of this analysis cannot be quantified in terms of risk since the baseline risk is not defined by the particular analyses summarized in the Blo.

\subsection{Redundancy Requirement}

The reliability study (Braun, 1997.) concluded that the system has a high degree of reliability as constructed, both in absolute terms and in comparison with the antiquated 702-A system it wi11 replace. Table 4.3.1 summarizes the conclusions. 
HNF-1788 Rev. 0

Table 4.3.1.

\begin{tabular}{|c|c|c|c|}
\hline Variation & $\begin{array}{c}\text { Existing 702-A } \\
\text { System }\end{array}$ & \multicolumn{2}{|c|}{ Project W-030 System } \\
\hline Basic System & $90.29 \%$ & \multicolumn{2}{|c|}{$99.15 \%$} \\
\hline System Aging & $72.34 \%$ & Safety Significant & Safety Class \\
\hline Seismic/High Wind & & $98.60 \%$ & $98.98 \%$ \\
\hline HCLPF $^{1}$ & & $99.06 \%$ & $99.13 \%$ \\
\hline
\end{tabular}

${ }_{1}$ High Confidence with Low Probability of Failure

As Table 4.3.1 indicates there is little to gain in increased reliability by replacing components with SC equivalents. The system is designed with several redundant features that include two separate filter trains, two fans, back-up power, two vacuum pumps (to support the CAM) and the ability to bypass components. The only major piece of equipment that can not be bypassed is the ductwork from the tanks to the ventilation train. The only criteria that is not met to assure the ductwork remains functional is seismic loading. As Table 4.3.1 indicates the increase in reliability upon meeting the criteria is insignificant. Therefore, it is acceptable as is.

Discussion of the reliability question must also consider any completion time identified in the authorization basis to enable repairs or replacement of failed components (Kriskovich, 1997d).

\subsection{Electrical Power Requirements}

The reliability study for the electrical power supply for the Project W-030 ventilation system (Kriskovich, 1997c) concluded there is also a high degree of reliability in both the utility electrical power supply and the facility electrical supply distribution (Normal Power Supply) to the exhaust fans. The study demonstrated that postulated failures of the electrical distribution system will be significantly less than 72 hours. In fact, the study shows that the overall fajlure rate for loss of motive power is approximately $1.5 \mathrm{E}-2$ per year with outage times ranging from 6 to 44 hours. Because of these findings, the Standby Electrical System is unlikely to be operated for extended periods of time, and any modifications or upgrades will not result in a significant increase in overall reliability of the ventilation system. This is also confirmed in Table 4.3.1.

\subsection{CONCLUSION}

The foregoing discussion evaluated equipment, originally procured and designed for the 241-AY/AZ Project $W-030$ ventilation upgrade for use in SS (and, sometimes, GS) applications, from the standpoint of the BIO accident analyses that reclassify the system as SC. A review of submitted documentation and review of design analyses demonstrates that most equipment meeting SS criteria also meets the requirements for SC. The remaining SS 
HNF-1788 Rev. 0

items, and other items that were procured and designed GS and now have a SS or SC safety function identified, would normally require a dedication process, replacement, reconfiguration or additional analysis if they are to be used in a safety application. These items are tabulated in Table 4.1.1 in Section 4.0, Results are identified in Section 4.2, Natural Phenomena Hazards Mitigation.

It is concluded that the deficiencies are not sufficient to justify the cost of such an upgrade. Reliability studies of the system and design analyses support this conclusion.

The report completed (Kriskovich, 1997b) supports this conclusion. That report identified several different alternatives to be completed to resolve the SC requirement issues discussed above along with costs associated with each alternative. Based on the costs and level of effort for each activity, the conclusion from that report supports these conclusions.

\subsection{RECOMMENDATIONS}

It is recommended that the system, as designed and procured, without modification, be accepted for SC application based on the technical information presented in this report and the fact that most safety SSCs were procured and designed to appropriate requirements. For those items originaliy procured and designed based on differing safety functions or designated GS, reliability studies and design analyses demonstrate that the added benefit of component replacements, system modifications, or additional engineering analyses to upgrade to SC do not provide a significant increase in reliability for the system or a reduction in risk. This recommendation is also based on the conclusions and recommendations from the alternative study (Kriskovich, 1997b) that identified the costs and level of effort to complete each a) ternative.

Meeting the natural phenomena criteria as identified in DOE order 6430.1A and GC-Load-01 is still required. Although existing ventilation systems in other farms and the existing 702-A System do not meet and no plans are in place to meet the requirement, it is recommended that a waiver be pursued against $6430.1 \mathrm{~A}$ SC seismic natural phenomena criteria for Project $W-030$ system/components. The waiver would be valid for the equipment currently installed and for any changes/modifications in the future (i.e., like for like replacement). Although the system and applicable components would be designated as SC, those changes/modifications would be completed to the original criteria as identified in this report. The technical bases to support the deviation are contained or referenced within this report. A rough order of magnitude cost estimate associated with this recommendation along with a schedule are identified in HNF-1518 (Kriskovich, 1997b).

If the above alternative is unacceptable, as an alternative, either a decision will need to be made on the applicability of DOE Order 6430.1A, or parts of the system will require additional analysis or physical upgrade to SC criteria, particularly the ductwork and valving downstream of the primary HEPA filters, discussed above as not satisfying applicable SC requirements under the new BIO criteria, and any pipe hangers and equipment supports identified 
HNF-1788 Rev. 0

as SC. The review process for each component in question should include one or more of the following steps:

- Determine which criteria are applicable to the item.

- Document nonconformance of item by means of NCR process.

- Contact vendor to determine if QA program is acceptable, and applicable to the item; conduct source inspection or other evaluation as appropriate.

- Contact other sites (e.g., commercial) to inquire about similar equipment that has been qualified to similar requirements, to estabijish a history of satisfactory performance in SC applications.

- Take samples for analysis to verify materials, where CMTRs do not exist (e.g., for pipe supports).

- Test or otherwise qualify item to verify critical characteristics (in place or temporarily removed from the system).

- Replace with equivalent items that are procured and qualified as safety SSCS, or reconfigure the system in such a way that the item is bypassed and its safety function is performed by other components.

- Possibly perform additional design anàlysis.

\subsection{REFERENCES}

Braun, D.J., 1997, Reliability Study of the 702-A and 702-AZ Ventilation Systems, HNF-SD-WM-CN-123, Rev. 0, Fluor Daniel Northwest, Richland, Washington.

DOE, 1989, General Design Criteria, DOE Order 6430.1A, U.S. Department of Energy, Washington, D.C. Aprii 6, 1989.

DOE-RL, 1997a, Contract Number DE-AC06-96RL13200 - Approval of Key Documents for Addition to the Tank Waste Remediation System (TWRS) Authorization Basis, Letter 97-MSD-211, J.D. Wagoner (DOE-RL) to H.J. Hatch. (Fluor Daniel Hanford, Inc.), dated May 30, 1997, Department of Energy, Richiand Operations, Richland, Washington.

DOE-RL, 1997b, Safety Evaluation Report for 702-AZ Ventilation System (241-AZ-702) Safety Analysis, enclosure to DOE RL Letter, J. D. Wagoner to H. J. Hatch, FDH, Contract Number DE-ACO6-96RL13200 - Approval of the 702-AZ Ventilation System Safety Basis as Addendum Three to the Tank Waste Remediation System (TWRS) Basis for Interim Operation (BIO), Revision OC, Project W-030 Licensing and Implementation Strategy and Safety Evaluation Report (SER), 97-WSD-212, September 29, 1997. 
DOE-RL, 1993, Standard Architectura7-Civi7 Design Criteria, Design Loads for Facilities. DOE-RL-SDC-4.1, Rev. 11, U.S. Department of Energy, Richland, Washington.

ICF KH, 1996, Design Loads for Facilities, A/E Standard - Civil/Structural, GC-Load-01, ICF KH, Richland, Washington.

Kriskovich, J.R., 1997a, Project W-030 Safety Equipment Evaluation, HNF-SD-W030-RPT-001, Rev. 0, Lockheed Martin Hanford Corporation, Richland, Washington.

Kriskovich, J.R., 1997b, Project W-030 Ventilation System Safety Class Upgrade Cost Estimate, HNF-1518, Rev. 0, Lockheed Martin Hanford Corporation, Richland, Washington.

Kriskovich, J.R., 1997c, Reliability Evaluation Electrical Power Distribution System for Tank Farm Ventilation System Primary Exhaust Fans Building 241-AZ-702, HNF-SD-W030-ANAL-003, Rev. 0, Lockheed Mart in Hanford Corporation, Richland, Washington.

Kriskovich, J.R., 1997d, Safety C7ass Evaluation of Project W-030, HNF-SD-W030-TI-001, Rev. 0, Lockheed Mart in Hanford Corporation, Richland, Washington.

LMHC, 1997a, Replacement Item Eva7uation, Commercial Grade Item Dedication and Upgrade, Vo1. IV, Sec. 3.11, HNF-PRO-0842, Rev. OA, Lockheed Martin Hanford Corp., Richland, Washington.

LMHC, 1997b, Tank Waste Remediation System Basis for Interim Operation, HNF-SD-WM-BI0-001, Rev 0-G, Lockheed Martin Hanford Company, Richland, Washington.

LMHC; 1997c, Tank Waste Remediation System Technica7 Safety Requirements, HNF-SD-WM-TSR-006, Rev. 0-I, Lockheed Mart in Hanford Company, Rich? and, Washington.

PHMC, 1997a, Project Hanford Policy and Procedure System - Engineering Design and Evaluation, HNF-PRO-097, Rev. 0, Fluor Daniel Hanford, Inc., Richland, Washington.

PHMC, 1997b, Project Hanford Policy and Procedure System - Procurement of Safety Structures, Systems and Components and Management Spares, HNF-PRO-447, Rev. 0 , (formerly Sec. EP 5.3 of WHC-CM-6-1, Standard Engineering Practices), Fluor Daniel Hanford, Inc., Richland, Washington.

PHMC, 1997c, Project Hanford Policy and Procedure System - Safety Structures Systems and Components, HNF-PR0-516, Rev. 0, (formerly Section 9.0 of WHC-CM-4-46, Safety Analysis Manua7), Fluor Daniel Hanford, Inc., Richland, Washington.

WHC, 1993, Preliminary Safety Equipment List for Tank Farm Ventilation Upgrade, Project W-030, WHC-SD-W030-SEL-001, Rev. O-A, Westinghouse Hanford Company, Richland, Washington. 
HNF-1788 Rev. 0

APPENDIX A

SAFETY EQUIPMENT LIST

A-1 
Table A-1. Active Ventilation for 241-AY/AZ, Project W-030 Ventilation Upgrade. (11 Sheets)

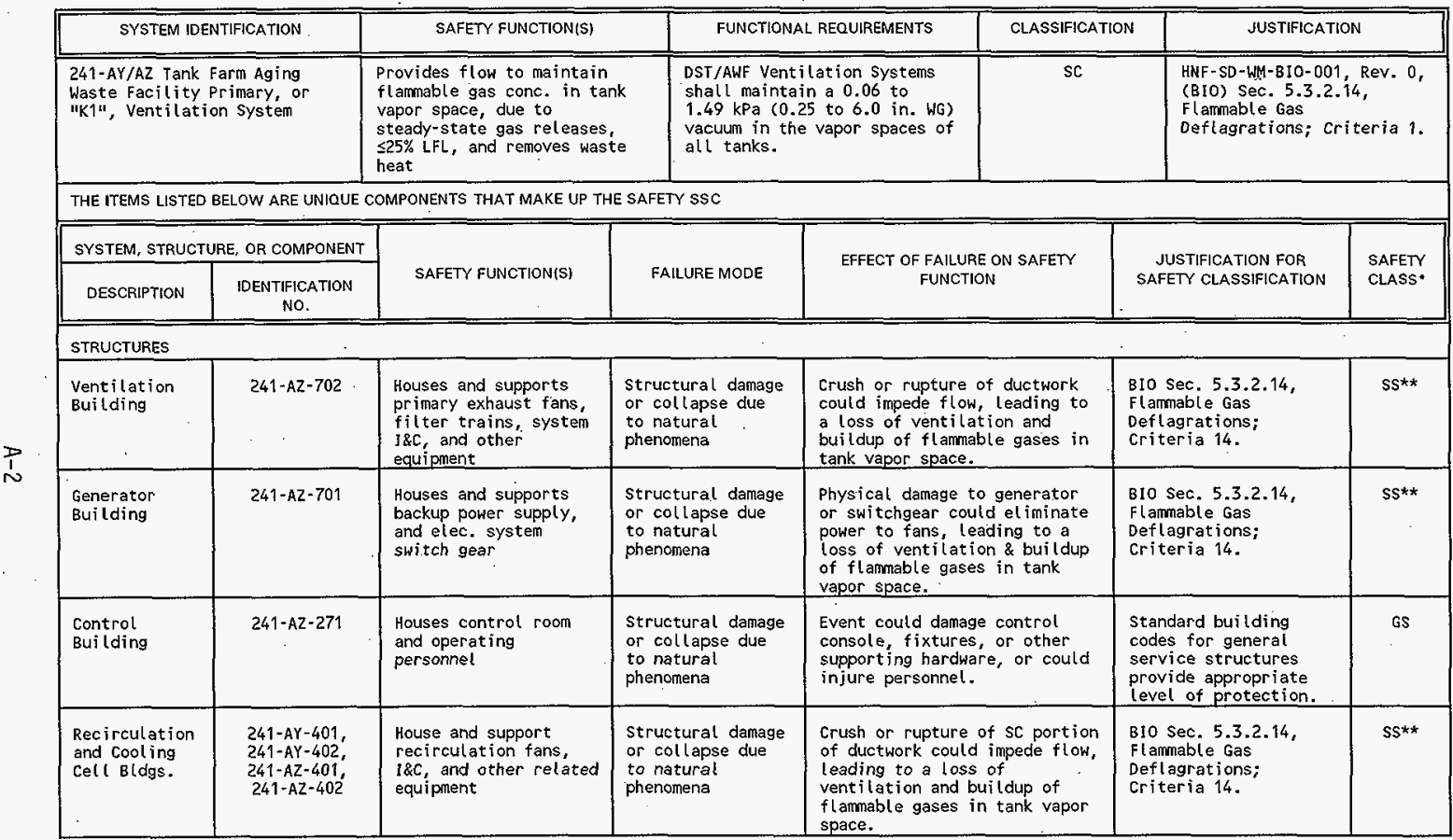


Table A-1. Active Ventilation for 241-AY/AZ, Project W-030 Ventilation Upgrade. (11 Sheets)

\begin{tabular}{|c|c|c|c|c|c|c|}
\hline \multicolumn{2}{|c|}{ SYSTEM, STRUCTURE, OR COMPONENT } & \multirow{2}{*}{ SAFETY FUNCTION(S) } & \multirow{2}{*}{ FALUURE MODE } & \multirow{2}{*}{$\begin{array}{l}\text { EFFECT OF FAILURE ON SAFETY } \\
\text { FUNCTION }\end{array}$} & \multirow{2}{*}{$\begin{array}{l}\text { JUSTIFICATION FOR } \\
\text { SAFETY GLASSIFICATION }\end{array}$} & \multirow{2}{*}{$\begin{array}{l}\text { SAFETY } \\
\text { CLASS: }\end{array}$} \\
\hline DESCRIPTION & $\begin{array}{l}\text { IDENTIFICATION } \\
\text { NO. } \\
\end{array}$ & & & & & \\
\hline $\begin{array}{l}\text { Piping and } \\
\text { equipment } \\
\text { supports }\end{array}$ & - & $\begin{array}{l}\text { Prevents loss of } \\
\text { components due to } \\
\text { natural. phenomena; } \\
\text { safety classification } \\
\text { to match component } \\
\text { supported. }\end{array}$ & $\begin{array}{l}\text { Structural damage } \\
\text { or col lapse due } \\
\text { to natural } \\
\text { phenomena, } \\
\text { affecting } \\
\text { integrity or } \\
\text { function of } \\
\text { supported } \\
\text { equipment }\end{array}$ & $\begin{array}{l}\text { Damage to } s c \text { ductwork or } \mathrm{SC} \\
\text { equipment could impede flow, } \\
\text { leading to a loss of } \\
\text { ventilation and buildup of } \\
\text { flammable gases in tank vapor } \\
\text { space; loss of non-sc equip. } \\
\text { does not affect system safety } \\
\text { function. }\end{array}$ & $\begin{array}{l}\text { Supports for primary } \\
\text { fans, filter trains, } \\
\text { SC dampers, and SC } \\
\text { ductwork are "SC", as } \\
\text { fai lure could cause } \\
\text { loss of flow; BIO Sec. } \\
5.3 .2 .14 \text {, Flammable } \\
\text { Gas Deflagrations; } \\
\text { Criteria } 14 ; \text { (supports } \\
\text { are "GS" for HEME, } \\
\text { condensers, recirc. } \\
\text { loop ductwork, other } \\
\text { GS equip. and piping). }\end{array}$ & $\begin{array}{l}\text { GS or } \\
\text { SC }\end{array}$ \\
\hline $\begin{array}{l}\text { Primary Vent } \\
\text { Exhaust stack }\end{array}$ & $296-A-42$ & $\begin{array}{l}\text { Exhausts filtered } \\
\text { primary flow to } \\
\text { atmosphere; minimizes } \\
\text { exposure of onsite } \\
\text { worker under abnormal } \\
\text { conditions (unfiltered } \\
\text { release) by elevating } \\
\text { discharge point and } \\
\text { enhancing dispersal of } \\
\text { effluent. }\end{array}$ & $\begin{array}{l}\text { Structural damage } \\
\text { or collapse due } \\
\text { to natural } \\
\text { phenomena }\end{array}$ & $\begin{array}{l}\text { Loss of stack does not prevent } \\
\text { flow and does not immediately } \\
\text { prevent system from performing } \\
\text { safety function. }\end{array}$ & $\begin{array}{l}\text { structural faiture } \\
\text { could affect worker } \\
\text { safety, but standard } \\
\text { building codes for } \\
\text { general service } \\
\text { structures provide } \\
\text { appropriate level of } \\
\text { protection. }\end{array}$ & GS \\
\hline \multicolumn{7}{|c|}{ MECHANICAL EQUIPMENT } \\
\hline $\begin{array}{l}\text { Primary } \\
\text { Exhaust fans }\end{array}$ & $\begin{array}{l}A Z-K 1-5-1 A ; \\
A Z-K 1-5-1 B\end{array}$ & $\begin{array}{l}\text { Provide primary } \\
\text { exhaust flow, to } \\
\text { prevent accumulation } \\
\text { of flammable gases. }\end{array}$ & $\begin{array}{l}\text { Mech. failure of } \\
\text { bearings, motor, } \\
\text { or drive, loss of } \\
\text { power, or struc. } \\
\text { failure of fan } \\
\text { housing. }\end{array}$ & $\begin{array}{l}\text { Failure of fan could eliminate } \\
\text { the motive force providing } \\
\text { flow, resulting in increased } \\
\text { flammable gas conc. in tank } \\
\text { vapor space (fan and filter } \\
\text { bank are redundant and can be } \\
\text { switched, but offline/standby } \\
\text { fan may be out of service) }\end{array}$ & $\begin{array}{l}\text { BIo sec. } 5.3 .2 .14, \\
\text { Flammable Gas } \\
\text { Deflagrations; } \\
\text { Criteria 1. }\end{array}$ & $\mathrm{sc}$ \\
\hline
\end{tabular}


Table A-1. Active Ventilation for 241-AY/AZ, Project W-030 Ventilation Upgrade. (11 Sheets)

\begin{tabular}{|c|c|c|c|c|c|c|}
\hline \multicolumn{2}{|c|}{ SYSTEM, STRUCTURE, OR COMPONENT } & \multirow{2}{*}{ SAFETY FUNCTION(S) } & \multirow{2}{*}{ FALLURE MODE } & \multirow{2}{*}{$\begin{array}{l}\text { EFFECT OF FAILURE ON SAFETY } \\
\text { FUNCTION }\end{array}$} & \multirow{2}{*}{$\begin{array}{l}\text { JUSTIFICATION FOR } \\
\text { SAFETY CLASSIFICATION }\end{array}$} & \multirow{2}{*}{$\begin{array}{l}\text { SAFETY } \\
\text { CLASS. }\end{array}$} \\
\hline DESCRIPTION & $\begin{array}{l}\text { IDENTIFICATION } \\
\text { NO. }\end{array}$ & & & & & \\
\hline $\begin{array}{l}\text { Ventilation } \\
\text { Ductwork from } \\
\text { Tank, incl. } \\
\text { equip. bypass } \\
\text { lines and } \\
\text { bypass } \\
\text { portions of } \\
\text { Recirculation } \\
\text { Loops (ref. } \\
\text { P\&IDs } \\
\text { H-2-131062-H- } \\
2-131065 \text {, } \\
\text { H-2-131075, \& } \\
\text { H-2-131076) }\end{array}$ & 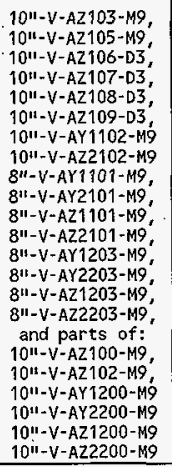 & $\begin{array}{l}\text { Provides a confined } \\
\text { path for primary flow } \\
\text { from tanks. }\end{array}$ & $\begin{array}{l}\text { Structural damage } \\
\text { or faiture } \\
\text { (crushing or } \\
\text { rupturing) }\end{array}$ & $\begin{array}{l}\text { Ductwork is nonredundant and } \\
\text { loss would preclude air flow } \\
\text { from tank, leading to a loss } \\
\text { of ventilation and buildup of } \\
\text { flammable gases in tank vapor } \\
\text { space }\end{array}$ & $\begin{array}{l}\text { Blo Sec. } 5.3 .2 .14, \\
\text { Flammable Gas } \\
\text { Deflagrations; } \\
\text { Criteria } 14 .\end{array}$ & sc \\
\hline $\begin{array}{l}\text { Ventilation } \\
\text { Ductwork from } \\
\text { Tank Air } \\
\text { Inlet Station } \\
\text { to Tank }\end{array}$ & $\begin{array}{l}\text { 6"-V-AY1100-M9, } \\
\text { 6"-V-AY2100-M9; } \\
\text { 6"-VAZ1100-M9; } \\
\text { 6"-V-AZ2100-M9' }\end{array}$ & $\begin{array}{l}\text { Confinement of } \\
\text { radiological and } \\
\text { hazardous materials; } \\
\text { provides a flow path } \\
\text { for fresh air into the } \\
\text { tank. }\end{array}$ & $\begin{array}{l}\text { Structural damage } \\
\text { or failure } \\
\text { (crushing) }\end{array}$ & $\begin{array}{l}\text { Ductwork is nonredundant and } \\
\text { loss could preclude fresh air } \\
\text { flow into tank, leading to a } \\
\text { loss of ventilation and } \\
\text { buildup of flammable gases in } \\
\text { tank vapor space }\end{array}$ & $\begin{array}{l}\text { Primary pathway for } \\
\text { air into the tank; } \\
\text { failure could prevent } \\
\text { flow; BI0 Sec. } \\
\text { 5.3.2.14, Flammable } \\
\text { Gas Deflagrations: } \\
\text { Criteria 14. }\end{array}$ & sc \\
\hline $\begin{array}{l}\text { Vent ilation } \\
\text { Duatwork from } \\
\text { Tank, routed } \\
\text { through HEME } \\
\text { and primary } \\
\text { condenser in } \\
\text { non-bypass } \\
\text { mode (ref. } \\
\text { P\&ID } \\
\text { H-2-131075) }\end{array}$ & 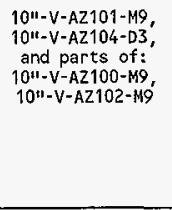 & $\begin{array}{l}\text { Provides a confined } \\
\text { path for primary flow } \\
\text { from tanks under } \\
\text { normal conditions, but } \\
\text { can be bypassed for } \\
\text { HEME and condenser } \\
\text { maintenance, etc. }\end{array}$ & $\begin{array}{l}\text { Structural damage } \\
\text { or } f \text { ai lure } \\
\text { (crushing or } \\
\text { rupturing) }\end{array}$ & $\begin{array}{l}\text { Ductwork is nonredundant but } \\
\text { may be bypassed in case of } \\
\text { loss, and would not preclude. } \\
\text { air flow from tank; loss would } \\
\text { affect efficiency but not } \\
\text { safety function of system. }\end{array}$ & $\begin{array}{l}\text { Ductwork is } \\
\text { nonredundant but may } \\
\text { be bypassed. }\end{array}$ & GS \\
\hline
\end{tabular}


Table A-1. Active Ventilation for 241-AY/AZ, Project W-030 Ventilation Upgrade. (11 Sheets)

\begin{tabular}{|c|c|c|c|c|c|c|}
\hline \multicolumn{2}{|c|}{ SYSTEM, STRUCTURE, OR COMPONENT } & \multirow{2}{*}{ SAFETY FUNCTION(S) } & \multirow[b]{2}{*}{ FAILURE MODE } & \multirow{2}{*}{$\begin{array}{l}\text { EFFECT OF FAILURE ON SAFETY } \\
\text { FUNCTION }\end{array}$} & \multirow{2}{*}{$\begin{array}{l}\text { JUSTIFICATION FOR } \\
\text { SAFETY CLASSIFICATION }\end{array}$} & \multirow{2}{*}{$\begin{array}{l}\text { SAFETY } \\
\text { CLASS }\end{array}$} \\
\hline DESCRIPTION & $\begin{array}{l}\text { IDENTIFICATION } \\
\text { NO. }\end{array}$ & & & & & \\
\hline $\begin{array}{l}\text { Ventilation } \\
\text { Ductwork, } \\
\text { Recirculation } \\
\text { Cool ing } \\
\text { System Loop } \\
\text { in non-bypass } \\
\text { mode (ref. } \\
\text { PQ1Ds } \\
\text { H-2-131062-H- } \\
2-131065 \text { ) }\end{array}$ & 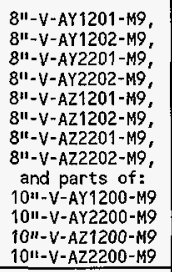 & $\begin{array}{l}\text { Confinement of } \\
\text { radiological and } \\
\text { hazardous materials; } \\
\text { provides path for } \\
\text { normal recirculation } \\
\text { flow path. }\end{array}$ & $\begin{array}{l}\text { Structural damage } \\
\text { or failure } \\
\text { (crushing, } \\
\text { plugging, or } \\
\text { rupturing) }\end{array}$ & $\begin{array}{l}\text { Ductwork is nonredundant but } \\
\text { may be bypassed in case of } \\
\text { loss, and would not preclude } \\
\text { air flow from tank; loss would } \\
\text { affect efficiency but not } \\
\text { safety function of system. }\end{array}$ & $\begin{array}{l}\text { Nonredundant, but can } \\
\text { be bypassed; failure } \\
\text { affects eff ficiency but } \\
\text { not safety function of } \\
\text { vent system. }\end{array}$ & GS \\
\hline $\begin{array}{l}\text { Motor } \\
\text { Operated } \\
\text { Dampers, } \\
\text { upstream and } \\
\text { downstream of } \\
\text { either filter } \\
\text { train }\end{array}$ & $\begin{array}{l}\text { MK-AZK1-1A, } \\
\text { MK-AZK1-1B, } \\
\text { MK-AZK1-2A, } \\
\text { MK-AZK1-2B }\end{array}$ & $\begin{array}{l}\text { Part of primary flow } \\
\text { path from tanks, or } \\
\text { part of confinement } \\
\text { barrier; used to route } \\
\text { or reroute primary } \\
\text { flow automatically } \\
\text { (i.e.e to switch } \\
\text { exhaust trains). }\end{array}$ & $\begin{array}{l}\text { Mechanical or } \\
\text { electrical } \\
\text { failure of damper } \\
\text { actuator; } \\
\text { structural } \\
\text { failure of damper } \\
\text { body; any failure } \\
\text { of damper in a } \\
\text { closed or open } \\
\text { position. }\end{array}$ & $\begin{array}{l}\text { Damper failure could preclude } \\
\text { air flow from tank, leading to } \\
\text { a loss of ventilation and } \\
\text { bui ldup of flamable gases in } \\
\text { tank vapor space. }\end{array}$ & $\begin{array}{l}\text { Failure of dampers } \\
\text { would prevent flow; } \\
\text { Blo sec. } 5.3 .2 .14 \text {; } \\
\text { Flammable Gas } \\
\text { Deftagrations; } \\
\text { Criteria 14. }\end{array}$ & sc \\
\hline $\begin{array}{l}\text { Motor } \\
\text { Operated } \\
\text { Dampers, Tank } \\
\text { Air Inlets }\end{array}$ & $\begin{array}{l}\text { MK-AY101K1-1, } \\
\text { MK-AY102K1-1, } \\
\text { MK-AZ101K1-1, } \\
\text { MK-AZ102K1-1 }\end{array}$ & $\begin{array}{l}\text { Provide a flow path } \\
\text { for fresh air into the } \\
\text { tank. }\end{array}$ & $\begin{array}{l}\text { Mech. or elec. } \\
\text { failure of damper } \\
\text { actuator; } \\
\text { structural } \\
\text { failure of damper } \\
\text { body; any failure } \\
\text { of damper in a } \\
\text { closed position. } \\
\end{array}$ & $\begin{array}{l}\text { Damper fai lure would preclude } \\
\text { fresh air flow into tank, } \\
\text { leading to a loss of } \\
\text { ventilation and buildup of } \\
\text { flamnatie gases in tank vapor } \\
\text { space. }\end{array}$ & $\begin{array}{l}\text { Primary pathway for } \\
\text { air into the tank; } \\
\text { failure of dampers in } \\
\text { closed position could } \\
\text { prevent flow; BIo Sec. } \\
5.3 .2 .14 \text {, Flammable } \\
\text { Gas Deflagrations; } \\
\text { Criteria 14. }\end{array}$ & sc \\
\hline $\begin{array}{l}\text { Motor } \\
\text { Operated flow } \\
\text { Control } \\
\text { Dampers, } \\
\text { outlet from } \\
\text { Tank }\end{array}$ & $\begin{array}{l}\text { MK-AY101K1-2, } \\
\text { MK-AY102K1-2, } \\
\text { MK-AZ101K1-2, } \\
\text { MK-AZ102K1-2 }\end{array}$ & $\begin{array}{l}\text { Part of primary flow } \\
\text { path from tanks; used } \\
\text { to regulate flow from } \\
\text { each tank and balance } \\
\text { system automatically; } \\
\text { may be isolated and } \\
\text { bypassed by manual } \\
\text { dampers. }\end{array}$ & $\begin{array}{l}\text { Mechanical or } \\
\text { electrical } \\
\text { failure of damper } \\
\text { actuator; } \\
\text { structurá } \\
\text { failure of damper } \\
\text { body; any failure } \\
\text { of damper in a } \\
\text { closed or open } \\
\text { position. }\end{array}$ & $\begin{array}{l}\text { Damper failure does not } \\
\text { eliminate flow or ability to } \\
\text { control primary flow or system } \\
\text { balance; damper may be } \\
\text { bypassed and flow adjusted } \\
\text { using manual bypass damper and } \\
\text { flow indicating instruments. }\end{array}$ & $\begin{array}{l}\text { Damper failure does } \\
\text { not affect system } \\
\text { safety function. }\end{array}$ & GS \\
\hline
\end{tabular}


Table A-1. Active Ventilation for 241-AY/AZ, Project W-030 Ventilation Upgrade. (11 Sheets)

\begin{tabular}{|c|c|c|c|c|c|c|}
\hline \multicolumn{2}{|c|}{ SYSTEM, STRUCTURE, OR COMPONENT } & \multirow{2}{*}{ SAFETY FUNCTION(S) } & \multirow{2}{*}{ FAILURE MODE } & \multirow{2}{*}{$\begin{array}{l}\text { EFFECT OF FAILURE ON SAFETY } \\
\text { FUNCTION }\end{array}$} & \multirow{2}{*}{$\begin{array}{l}\text { JUSTIFICATION FOR } \\
\text { SAFETY CLASSIFICATION }\end{array}$} & \multirow{2}{*}{$\begin{array}{l}\text { SAFETY } \\
\text { CLASS: }\end{array}$} \\
\hline DESCRIPTION & $\begin{array}{l}\text { IDENTIFICATION } \\
\text { NO. }\end{array}$ & & & & & \\
\hline $\begin{array}{l}\text { Hanually } \\
\text { Operated } \\
\text { Dampers, } \\
\text { bypass and } \\
\text { isolation for } \\
\text { primary flow } \\
\text { path around } \\
\text { flow control } \\
\text { dampers }\end{array}$ & $\begin{array}{l}\text { MK-AY101K1-2A1, } \\
\text { MK-AY101K1-2A2, } \\
\text { MK-AY101K1-2A3 } \\
\text { (similar, for } \\
\text { other } 3 \text { tanks; } \\
\text { ref. P\&ID } \\
\text { H-2-i31075) }\end{array}$ & $\begin{array}{l}\text { Part of normal primary } \\
\text { flow path from tanks, } \\
\text { or part of confinement } \\
\text { barrier (with } \\
\text { ductwork) when motor } \\
\text { operated flow control } \\
\text { damper is bypassed for } \\
\text { maintenance. }\end{array}$ & $\begin{array}{l}\text { Mechanical } \\
\text { failure of } \\
\text { damper; } \\
\text { structural } \\
\text { failure of damper } \\
\text { body. }\end{array}$ & $\begin{array}{l}\text { Failure of isolation dampers } \\
\text { in open position, or bypass } \\
\text { damper in a closed position, } \\
\text { concurrent with a failure of } \\
\text { flow control damper, could } \\
\text { limit ventilation flow from } \\
\text { tank, leading to a buildup of } \\
\text { flammable gases in tank vapor } \\
\text { space. }\end{array}$ & $\begin{array}{l}\text { Used to bypass flow } \\
\text { control damper; damper } \\
\text { failure could prevent } \\
\text { or limit flow; 8to } \\
\text { Sec. } 5.3 .2 .14 \text {; } \\
\text { Flamable Gas } \\
\text { Deflagrations; } \\
\text { Criteria } 14 \text {. }\end{array}$ & SC \\
\hline $\begin{array}{l}\text { Manually } \\
\text { Operated } \\
\text { Dampers, } \\
\text { Recirc. Loop } \\
\text { (bypass and } \\
\text { isolation } \\
\text { dampers for } \\
\text { primary flow } \\
\text { path) }\end{array}$ & $\begin{array}{l}\text { MK-AY101K4-1, } \\
\text { MK-AY101K4-2, } \\
\text { MK-AY101K4-3, } \\
\text { MK-AY101K4-4 } \\
\text { (similar, for } \\
\text { other } 3 \text { tanks; } \\
\text { ref. P\&IDs } \\
\text { H-2-131062-H-2* } \\
\text { 131065) }\end{array}$ & $\begin{array}{l}\text { Part of primary flow } \\
\text { path from tanks, or } \\
\text { part of confinement } \\
\text { barrier (with } \\
\text { ductwork) when recirc. } \\
\text { loop is bypassed. }\end{array}$ & $\begin{array}{l}\text { Mechanical } \\
\text { failure of damper } \\
\text { in an open } \\
\text { position; } \\
\text { structural } \\
\text { failure of damper } \\
\text { body. }\end{array}$ & $\begin{array}{l}\text { Damper failure concurrent with } \\
\text { a rupture in recirc. Loop } \\
\text { could limit ventilation flow } \\
\text { from tank, leading to a } \\
\text { buildup of flammable gases in } \\
\text { tank vapor space. }\end{array}$ & $\begin{array}{l}\text { Used to bypass recirc. } \\
\text { loop; failure of } \\
\text { isolation dampers in } \\
\text { open position could } \\
\text { prevent or limit flow; } \\
\text { Blo Sec. } 5.3 .2 .14 \text {, } \\
\text { Flammable Gas } \\
\text { Deflagrations; } \\
\text { Criteria } 14 \text {. }\end{array}$ & SC \\
\hline $\begin{array}{l}\text { Manual ly } \\
\text { operated } \\
\text { Dampers, } \\
\text { balance of } \\
\text { system, incl. } \\
\text { condenser and } \\
\text { HEME bypass } \\
\text { and isolation } \\
\text { dampers }\end{array}$ & $\begin{array}{l}\text { MK-AZK105-1A1, } \\
\text { MK-AZK105-1A2, } \\
\text { MK-AZK105-1B1, } \\
\text { MK-AZK105-1B2, } \\
\text { MK-AZK1-3A, } \\
\text { MK-AZK1-3B, } \\
\text { MK-AZK108-1A, } \\
\text { MK-AZK108-18, } \\
\text { MK-AZK108-1C, } \\
\text { MK-AZK109-1A, } \\
\text { MK-AZK109-1B, } \\
\text { MK-AZK109-1C }\end{array}$ & $\begin{array}{l}\text { Part of primary flow } \\
\text { path from tanks; used } \\
\text { to route or reroute } \\
\text { primary flow or bypass } \\
\text { equipment for } \\
\text { maintenance; may form } \\
\text { part of confinement } \\
\text { barrier if used for } \\
\text { isolation. }\end{array}$ & $\begin{array}{l}\text { Mechanical } \\
\text { failure of damper } \\
\text { in a closed or } \\
\text { open position; } \\
\text { structural } \\
\text { failure of damper } \\
\text { body. }\end{array}$ & $\begin{array}{l}\text { Damper failure could preclude } \\
\text { air flow from tank, leading to } \\
\text { a loss of ventilation and } \\
\text { buildup of flammable gases in } \\
\text { tank vapor space. }\end{array}$ & $\begin{array}{l}\text { Failure of dampers in } \\
\text { closed position (or of } \\
\text { isolation dampers in } \\
\text { open position) could } \\
\text { prevent flow; B10 Sec. } \\
5.3 .2 .14 \text {, Flammable } \\
\text { Gas Deflagrations; } \\
\text { Criteria 14. }\end{array}$ & $\mathrm{sc}$ \\
\hline $\begin{array}{l}\text { Primary HEPA } \\
\text { Filters }\end{array}$ & $\begin{array}{l}A Z-K 1-4-1 A \\
A Z-K 1-4-1 B \\
A Z-K 1-4-2 A \\
A Z-K 1-4-2 B\end{array}$ & $\begin{array}{l}\text { Confinement of } \\
\text { radiological and } \\
\text { hazardous materials; } \\
\text { hous ings form part of } \\
\text { primary flow path } \\
\text { conf inement barrier. }\end{array}$ & $\begin{array}{l}\text { Breach due to } \\
\text { high temperature } \\
\text { or pressure; } \\
\text { substantial } \\
\text { plugging due to } \\
\text { ice, moisture, or } \\
\text { dust buildup not } \\
\text { a credible event. }\end{array}$ & $\begin{array}{l}\text { Failure may result in exposure } \\
\text { of onsite worker, but does not } \\
\text { prevent flow; caM interlock } \\
\text { and diff. press. switches } \\
\text { provide appropriate level of } \\
\text { protection against onsite. } \\
\text { exposure. }\end{array}$ & $\begin{array}{l}\text { CAM interlock to fans } \\
\text { (part of radiation } \\
\text { monitoring system, } \\
\text { RAH-AZK1-1, ref. } \\
\text { H-2-131078) switches } \\
\text { fans/trains to provide } \\
\text { SSC control; diff. } \\
\text { press. switches } \\
\text { provide add'l } \\
\text { compensatory measure. }\end{array}$ & GS \\
\hline
\end{tabular}


Table A-1. Active Ventilation for 241-AY/AZ, Project W-030 Ventilation Upgrade. (11 Sheets)

\begin{tabular}{|c|c|c|c|c|c|c|}
\hline \multicolumn{2}{|c|}{ SYSTEM, STRUCTURE, OR COMPONENT } & \multirow{2}{*}{ SAFETY FUNCTION(S) } & \multirow[b]{2}{*}{ FAILURE MODE } & \multirow{2}{*}{$\begin{array}{c}\text { EFFECT OF FAILURE ON SAFETY } \\
\text { FUNCTION }\end{array}$} & \multirow{2}{*}{$\begin{array}{l}\text { JUSTIFICATION FOR } \\
\text { SAFETY CLASSIFICATION }\end{array}$} & \multirow{2}{*}{$\begin{array}{l}\text { SAFETY } \\
\text { CLASS" }\end{array}$} \\
\hline DESCRIPTION & $\begin{array}{l}\text { IDENTIFICATION } \\
\text { NO. } \\
\end{array}$ & & & & & \\
\hline $\begin{array}{l}\text { Primary HEGA } \\
\text { (Charcoal) } \\
\text { Filters }\end{array}$ & $\begin{array}{l}A Z=K 1-10-1 A \\
A Z-K 1-10-1 B\end{array}$ & $\begin{array}{l}\text { Confinement of } \\
\text { radiological and } \\
\text { hazardous materials; } \\
\text { housings form part of } \\
\text { primary flow path } \\
\text { confinement barrier. }\end{array}$ & $\begin{array}{l}\text { Breach due to } \\
\text { high temperature } \\
\text { or pressure; } \\
\text { substantial } \\
\text { plugging due to } \\
\text { ice, moisture, or } \\
\text { dust buildup not } \\
\text { a credible event. }\end{array}$ & $\begin{array}{l}\text { Failure may result in exposure } \\
\text { of onsite worker, but does not } \\
\text { prevent flow; CAM interlock } \\
\text { and diff. press. switches } \\
\text { provide appropriate level of } \\
\text { protection against onsite } \\
\text { exposure. }\end{array}$ & $\begin{array}{l}\text { CAM interlock provides } \\
\text { SSC controt; diff. } \\
\text { press. switches } \\
\text { provide add'! } \\
\text { compensatory measure. }\end{array}$ & GS \\
\hline $\begin{array}{l}\text { Primary } \\
\text { Heaters }\end{array}$ & $\begin{array}{l}A Z-K 1-2-1 A \\
A Z-K 1-2-1 B\end{array}$ & $\begin{array}{l}\text { Protects filters from } \\
\text { moisture damage and } \\
\text { improves efficiency, } \\
\text { by heating airstream, } \\
\text { aids in conf inentent of } \\
\text { radiological and } \\
\text { hazardous materials; } \\
\text { hous ings form part of } \\
\text { confinement barrier. }\end{array}$ & $\begin{array}{l}\text { Heater failure or } \\
\text { loss of power } \\
\text { resulting in loss } \\
\text { of airstream } \\
\text { heating; or } \\
\text { heater may } \\
\text { overheat and } \\
\text { damage filters. }\end{array}$ & $\begin{array}{l}\text { Keater failure may eventually } \\
\text { result in filter damage or } \\
\text { loss of filter efficiency. }\end{array}$ & $\begin{array}{l}\text { Faiture affects life } \\
\text { and efficiency of } \\
\text { filters, but has no } \\
\text { immediate effect on } \\
\text { flow or system safety } \\
\text { function. }\end{array}$ & GS \\
\hline HEME & $A Z-K 1-9-1$ & $\begin{array}{l}\text { Confinement of } \\
\text { radiological and } \\
\text { hazardous materials; } \\
\text { conf inement of } \\
\text { majority of tank } \\
\text { liquids to "hotter" } \\
\text { side of system to } \\
\text { reduce moisture, } \\
\text { salts, and } \\
\text { radiological load on } \\
\text { HEPA filters; shell } \\
\text { forms part of } \\
\text { confinement barrier. }\end{array}$ & $\begin{array}{l}\text { Mechanical } \\
\text { failure resulting } \\
\text { in carryover of } \\
\text { liquids to filter } \\
\text { train. }\end{array}$ & $\begin{array}{l}\text { Increased contamination levels } \\
\text { in HEPA/HEGA filter train and } \\
\text { reduced system efficiency. }\end{array}$ & $\begin{array}{l}\text { Nonredundant, but can } \\
\text { be bypassed; failure } \\
\text { affects efficiency but } \\
\text { not safety function. of } \\
\text { filters \& vent system, } \\
\text { and does not prevent } \\
\text { flow. }\end{array}$ & GS \\
\hline $\begin{array}{l}\text { Primary } \\
\text { Condenser }\end{array}$ & $A Z-K 1-8-1$ & $\begin{array}{l}\text { Confinement of } \\
\text { radiological and } \\
\text { hazardous materials; } \\
\text { confinement of } \\
\text { majority of tank } \\
\text { liquids to "hotter" } \\
\text { side of system to } \\
\text { reduce moisture, } \\
\text { salts, and } \\
\text { radiological load on } \\
\text { HEPA filters; - shell } \\
\text { forms part of } \\
\text { confinement barrier. }\end{array}$ & $\begin{array}{l}\text { Mechanical } \\
\text { failure resulting } \\
\text { in carryover of } \\
\text { liquids to filter } \\
\text { train. }\end{array}$ & $\begin{array}{l}\text { Increased contamination levels } \\
\text { in HEPA/HEGA filter train and } \\
\text { reduced system efficiency. }\end{array}$ & $\begin{array}{l}\text { Nonredundant, but can } \\
\text { be bypassed; failure } \\
\text { affects efficiency but } \\
\text { not safety function of } \\
\text { filters \& vent system, } \\
\text { and does not prevent } \\
\text { flow. }\end{array}$ & GS \\
\hline
\end{tabular}


Table A-1. Active Ventilation for 241-AY/AZ, Project W-030 Ventilation Upgrade. (11 Sheets)

\begin{tabular}{|c|c|c|c|c|c|c|}
\hline \multicolumn{2}{|c|}{ SYSTEM, STRUCTURE, OR COMPONENT } & \multirow{2}{*}{ SAFETY FUNCTIONIS) } & \multirow{2}{*}{ FAILURE MODE } & \multirow{2}{*}{$\begin{array}{l}\text { EFFECT OF FAILURE ON SAFETY } \\
\text { FUNCTION }\end{array}$} & \multirow{2}{*}{$\begin{array}{l}\text { JUSTIFICATION FOR } \\
\text { SAFETY CLASSIFICATION }\end{array}$} & \multirow{2}{*}{$\begin{array}{l}\text { SAFETY } \\
\text { CLASS* }\end{array}$} \\
\hline DESCRIPTION & $\begin{array}{l}\text { IDENTIFICATION } \\
\text { NO. } \\
\end{array}$ & & & & & \\
\hline $\begin{array}{l}\text { Primary Tank } \\
\text { and Risers }\end{array}$ & $\begin{array}{l}\text { TK-AY-101, } \\
\text { TK-AY-102, } \\
\text { TK-AZ-101, } \\
\text { TK-AZ-102 }\end{array}$ & $\begin{array}{l}\text { Primary confinement of } \\
\text { tank waste and vapors; } \\
\text { connects to air inlet } \\
\text { and exhaust } \\
\text { ventilation ductwork. }\end{array}$ & $\begin{array}{l}\text { Structural } \\
\text { failure of tank } \\
\text { or risers due to } \\
\text { natural } \\
\text { phenomena. }\end{array}$ & $\begin{array}{l}\text { Leakage or loss of confinement } \\
\text { of tank waste. }\end{array}$ & $\begin{array}{l}\text { Not classified; ref. } \\
\text { related note to this } \\
\text { table, or BIO } \\
\text { Sec. } 2.0 \text {. }\end{array}$ & *** \\
\hline $\begin{array}{l}\text { Tank Air. } \\
\text { Inlet HEPA } \\
\text { Filters }\end{array}$ & $\begin{array}{l}\text { AY } 101-K 4-4-1, \\
\text { AY102-K4-4-1, } \\
\text { AZ101-K4-4-1, } \\
\text { AZ102-K4-4-1 }\end{array}$ & $\begin{array}{l}\text { Confinement of } \\
\text { radiological and } \\
\text { hazardous materials; } \\
\text { housings form part of } \\
\text { conf inement barrier. }\end{array}$ & $\begin{array}{l}\text { Breach of filter } \\
\text { due to high } \\
\text { temperature or } \\
\text { pressure; } \\
\text { substantial } \\
\text { plugging due to } \\
\text { ice, moisture, or } \\
\text { dust buildup not } \\
\text { a credible event. }\end{array}$ & $\begin{array}{l}\text { Failed filter will not confine } \\
\text { tank atmosphere in the event } \\
\text { of a tank pressurization, with } \\
\text { poss. effect on onsite worker; } \\
\text { no effect on flow. }\end{array}$ & $\begin{array}{l}\text { Intet filters do not } \\
\text { carry a significant } \\
\text { inventory; confinement } \\
\text { function is } \\
\text { insignificant as it } \\
\text { applies only in case } \\
\text { of a tank } \\
\text { pressurization. }\end{array}$ & GS \\
\hline $\begin{array}{l}\text { Tank Air } \\
\text { Inlet } \\
\text { Prefilters }\end{array}$ & $\begin{array}{l}\text { AY } 101-K 4-3-1 \\
\text { AY } 102-K 4-3-1 \\
\text { AZ101-K4-3-1; } \\
\text { AZ102-K4-3-1 }\end{array}$ & $\begin{array}{l}\text { Helps protect } \\
\text { integrity. of air inlet } \\
\text { HEPA filter. }\end{array}$ & $\begin{array}{l}\text { Breach of filter } \\
\text { due to high } \\
\text { temperature or } \\
\text { pressure; } \\
\text { substantial } \\
\text { plugging due to } \\
\text { ice, moisture, or } \\
\text { dust bui ldup not } \\
\text { a credible event. }\end{array}$ & $\begin{array}{l}\text { Failed prefitter will allow } \\
\text { inlet HEPA filter to load up } \\
\text { faster and lose efficiency; no } \\
\text { immediate effect on system } \\
\text { safety function. }\end{array}$ & $\begin{array}{l}\text { Failure affects life } \\
\text { of air inlet HEPA } \\
\text { filters; no immediate } \\
\text { effect on confinement } \\
\text { function. }\end{array}$ & GS \\
\hline $\begin{array}{l}\text { Tank Air } \\
\text { Inlet Heaters }\end{array}$ & $\begin{array}{l}\text { AY101-K4-2-1, } \\
\text { AY102-K4-2-1, } \\
\text { AZ101-K4-2-1, } \\
\text { AZ102-K4-2-1 }\end{array}$ & $\begin{array}{l}\text { Helps protect } \\
\text { integrity of air inlet } \\
\text { HEPA filter, by } \\
\text { heating airstream. }\end{array}$ & $\begin{array}{l}\text { Heater failure or } \\
\text { loss of power } \\
\text { resulting in loss } \\
\text { of airstream } \\
\text { heating function; } \\
\text { alternatively, } \\
\text { heater may } \\
\text { overheat and } \\
\text { damage filter. }\end{array}$ & $\begin{array}{l}\text { Heater failure may eventually } \\
\text { result in filter damage or } \\
\text { loss of filter efficiency; no } \\
\text { effect on flow. } \\
\end{array}$ & $\begin{array}{l}\text { Failure affects life } \\
\text { of air inlet HEPA } \\
\text { filters; no immediate } \\
\text { effect on confinement } \\
\text { function or flow. }\end{array}$ & GS \\
\hline $\begin{array}{l}\text { Recirculation } \\
\text { Fans }\end{array}$ & $\begin{array}{l}\text { AY101-K4 }-5-1, \\
\text { AY102-K4 } \\
\text { AZ101-K4-1, } \\
\text { AZ102-K4-5-1; }\end{array}$ & $\begin{array}{l}\text { Provide recirculation } \\
\text { flow for waste/vent } \\
\text { cooting; housings form } \\
\text { part of confinement } \\
\text { barrier but not part } \\
\text { of primary flow path. }\end{array}$ & $\begin{array}{l}\text { Mech. failure of } \\
\text { bearings, motor, } \\
\text { or drive, loss of } \\
\text { power, or struc. } \\
\text { failure of fan } \\
\text { housing or } \\
\text { supports. }\end{array}$ & $\begin{array}{l}\text { Failure of fan could eliminate } \\
\text { the motive force providing } \\
\text { recirculation flow, resulting } \\
\text { in loss of cooling and } \\
\text { decreased system efficiency, } \\
\text { but not safety function. }\end{array}$ & $\begin{array}{l}\text { Nonredundant, but can } \\
\text { be bypassed; failure } \\
\text { limits waste cooling } \\
\text { function, affecting } \\
\text { efficiency but not } \\
\text { safety function of } \\
\text { vent system. }\end{array}$ & GS \\
\hline
\end{tabular}


Table A-1. Active Ventilation for 241-AY/AZ, Project W-030 Ventilation Upgrade. (11 Sheets)

\begin{tabular}{|c|c|c|c|c|c|c|}
\hline \multicolumn{2}{|c|}{ SYSTEM, STRUCTURE, OR COMPONENT } & \multirow{2}{*}{ SAFETY FUNCTION(S) } & \multirow{2}{*}{ FAILURE MODE } & \multirow{2}{*}{$\begin{array}{l}\text { EFFECT OF FAILURE ON SAFETY } \\
\text { FUNCTION }\end{array}$} & \multirow{2}{*}{$\begin{array}{l}\text { JUSTIFICATION FOR } \\
\text { SAFETY CLASSIFICATION }\end{array}$} & \multirow{2}{*}{$\begin{array}{l}\text { SAFETY } \\
\text { CLASS: }\end{array}$} \\
\hline DESCRIPTION & $\begin{array}{l}\text { IDENTIFICATION } \\
\text { NO. } \\
\end{array}$ & & & & & \\
\hline $\begin{array}{l}\text { Recirc. Loop } \\
\text { Moisture } \\
\text { Separators }\end{array}$ & $\begin{array}{l}\text { AY101-K4-1-1, } \\
\text { AY102-K4 } 1-1, \\
\text { AZ101-K4 } 1-1, \\
\text { AZ102-K4-1-1 }\end{array}$ & $\begin{array}{l}\text { Confinement of liquids } \\
\text { to tank and reduced } \\
\text { filter loading; } \\
\text { housings form part of } \\
\text { confinement barrier } \\
\text { but not part of } \\
\text { primary flow path. }\end{array}$ & $\begin{array}{l}\text { Mechanical } \\
\text { failure resulting } \\
\text { in carryover of } \\
\text { liquids and loss } \\
\text { of cooling, } \\
\text { systen } \\
\text { efficiency. }\end{array}$ & $\begin{array}{l}\text { Failure could result in loss } \\
\text { of cooling and decreased } \\
\text { system efficiency, but not } \\
\text { safety function. }\end{array}$ & $\begin{array}{l}\text { Nonredundant, but can } \\
\text { be bypassed; failure } \\
\text { affects efficiency but } \\
\text { not safety function of } \\
\text { system. }\end{array}$ & GS \\
\hline $\begin{array}{l}\text { Recirc. Loop } \\
\text { Moisture } \\
\text { Condensers }\end{array}$ & $\begin{array}{l}\text { AY101-K4-8-1, } \\
\text { AY102-K4-8-1, } \\
\text { AZ101-K4-8-1, } \\
\text { AZ102-K4-8-1 }\end{array}$ & $\begin{array}{l}\text { Waste/vent cooling; } \\
\text { confinement of liquids } \\
\text { to tank and reduced } \\
\text { filter loading; } \\
\text { housings form part of } \\
\text { confinement barrier } \\
\text { but not part of } \\
\text { primary flow path. }\end{array}$ & $\begin{array}{l}\text { Mechanical } \\
\text { failure resulting } \\
\text { in carryover of } \\
\text { liquids and loss } \\
\text { of cooling, } \\
\text { system } \\
\text { efficiency. }\end{array}$ & $\begin{array}{l}\text { Failure could result in loss } \\
\text { of cooling and decreased } \\
\text { system efficiency, but not } \\
\text { safety function. }\end{array}$ & $\begin{array}{l}\text { Nonredundant, but can } \\
\text { be bypassed; failure } \\
\text { affects efficiency but } \\
\text { not safety function of } \\
\text { system. }\end{array}$ & GS \\
\hline $\begin{array}{l}\text { Duct } \\
\text { encasements } \\
\text { (secondary } \\
\text { containnent } \\
\text { system) }\end{array}$ & $\begin{array}{c}\text { "ENC-M26" } \\
\text { various (ref. } \\
\text { P\&IDs } \\
H-2-131062-H-2- \\
131065 \& \\
H-2-131075 \text { ) } \\
\end{array}$ & $\begin{array}{l}\text { Contains condensate in } \\
\text { the event of leakage } \\
\text { from ductwork. }\end{array}$ & $\begin{array}{l}\text { Structural damage } \\
\text { or failure } \\
\text { (crushing or } \\
\text { rupturing) }\end{array}$ & $\begin{array}{l}\text { Encasement is nonredundant and } \\
\text { failure, if concurrent with a } \\
\text { piping or duct failure, would } \\
\text { result in loss of conf inenent } \\
\text { and liquid containment. }\end{array}$ & $\begin{array}{l}\text { Condensate is not a } \\
\text { significant source } \\
\text { term, and is not } \\
\text { included in BIO } \\
\text { accident scenarios. }\end{array}$ & GS \\
\hline $\begin{array}{l}\text { Process } \\
\text { condensate } \\
\text { drains }\end{array}$ & $\begin{array}{c}\text { "-PC- }-M 27^{\mathrm{H}} \\
\text { various (ref. } \\
\text { P\&IDS } \\
\mathrm{H}-2-131062-\mathrm{H}-2- \\
131065 \& \\
\mathrm{H}-2-131075 \text { ) }\end{array}$ & $\begin{array}{l}\text { Contains condensate } \\
\text { from various equipment }\end{array}$ & $\begin{array}{l}\text { Structural damage } \\
\text { or failure } \\
\text { (crushing, } \\
\text { plugging, or } \\
\text { rupturing) }\end{array}$ & $\begin{array}{l}\text { Piping is nonredundant and } \\
\text { failure would result in loss } \\
\text { of liquid containment. }\end{array}$ & $\begin{array}{l}\text { Condensate is not a } \\
\text { significant source } \\
\text { term, and is not } \\
\text { included in BIO } \\
\text { accident scenarios. }\end{array}$ & GS \\
\hline $\begin{array}{l}241-A Z-702 \\
\text { Building } \\
\text { Ventilation } \\
\text { (Subsystem) }\end{array}$ & $\begin{array}{l}\text { (Ref. } \\
H-2-131077 \& \\
H-2-131081)\end{array}$ & $\begin{array}{l}\text { Supplies cooling to } \\
\text { fan motors and drives. }\end{array}$ & $\begin{array}{l}\text { Mechanical } \\
\text { failure of fan or } \\
\text { other components, } \\
\text { loss of power. }\end{array}$ & $\begin{array}{l}\text { Loss of ventilation for } \\
\text { equipment cooling. }\end{array}$ & $\begin{array}{l}\text { Failure has no } \\
\text { immediate effect on } \\
\text { system safety } \\
\text { function. }\end{array}$ & GS \\
\hline \multicolumn{7}{|c|}{ ELECTRICAL AND I\&C EQUIPMENT } \\
\hline $\begin{array}{l}\text { Normal Power } \\
\text { Supply } \\
\text { (Subsystem) }\end{array}$ & $\begin{array}{l}\text { (Ref. } \\
H-2-131353 \\
\text { Sh. 1) }\end{array}$ & $\begin{array}{l}\text { Provide power to } \\
\text { exhaust fan drives. }\end{array}$ & $\begin{array}{l}\text { Loss of main } \\
\text { power source, } \\
\text { loss of } \\
\text { switchgear or } \\
\text { transformer. }\end{array}$ & $\begin{array}{l}\text { Failure of fan power supply } \\
\text { eliminates the motive force } \\
\text { providing flow, leading to a } \\
\text { buildup of flammable gases in } \\
\text { tank vapor space. }\end{array}$ & $\begin{array}{l}\text { Blo sec. } 5.3 .2 .14, \\
\text { Flamitable Gas } \\
\text { Deflagrations; } \\
\text { Criteria } 14 .\end{array}$ & SC \\
\hline
\end{tabular}


Table A-1. Active Ventilation for 24l-AY/AZ, Project W-030 Ventilation Upgrade. (11 Sheets)

\begin{tabular}{|c|c|c|c|c|c|c|}
\hline \multicolumn{2}{|c|}{ SYSTEM, STRUCTURE, OR COMPONENT } & \multirow{2}{*}{ SAFETY FUNCTION(S) } & \multirow{2}{*}{ FAILURE MODE } & \multirow{2}{*}{$\begin{array}{l}\text { EFFECT OF FAILURE ON SAFETY } \\
\text { FUNCTION }\end{array}$} & \multirow{2}{*}{$\begin{array}{l}\text { JUSTIFICATION FOR } \\
\text { SAFETY CLASSIFICATION }\end{array}$} & \multirow{2}{*}{$\begin{array}{l}\text { SAFETY } \\
\text { CLASS* }\end{array}$} \\
\hline DESCRIPTION & $\begin{array}{l}\text { IDENTIFICATION } \\
\text { NO. }\end{array}$ & & & & & \\
\hline $\begin{array}{l}\text { Backup Power } \\
\text { Supply } \\
\text { (subsystem) }\end{array}$ & $\begin{array}{l}\text { (Ref. } \\
H-2-131353, \\
\text { Sh. 2) }\end{array}$ & $\begin{array}{l}\text { Provide backup power } \\
\text { to exhaust fan drives } \\
\text { on loss of normal } \\
\text { power. }\end{array}$ & $\begin{array}{l}\text { Loss of diesel } \\
\text { fuel supply, } \\
\text { collapse of gen. } \\
\text { bldg., mech. } \\
\text { failure of } \\
\text { generator. }\end{array}$ & $\begin{array}{l}\text { Failure of fan power supply } \\
\text { el iminates the motive force } \\
\text { providing flow, leading to a } \\
\text { buildup of flamable gases in } \\
\text { tank vapor space. }\end{array}$ & $\begin{array}{l}\text { Blo Sec. } 5.3 .2 .14 \text {, } \\
\text { Flammable Gas } \\
\text { Deflagrations; } \\
\text { Criteria } 14 .\end{array}$ & SC \\
\hline $\begin{array}{l}\text { Variable } \\
\text { Speed Drives }\end{array}$ & VSD-1; vSD-2 & $\begin{array}{l}\text { Provide power to } \\
\text { exhaust fans. }\end{array}$ & $\begin{array}{l}\text { Loss or failure } \\
\text { of electrical } \\
\text { components by } \\
\text { overheating or } \\
\text { deterioration. }\end{array}$ & $\begin{array}{l}\text { Failure of fan drive } \\
\text { el iminates the motive force } \\
\text { providing flow, leading to a } \\
\text { buildup of flammable gases in } \\
\text { tank vapor space. }\end{array}$ & $\begin{array}{l}\text { Failure of fan } \\
\text { eliminates the motive } \\
\text { force providing flow; } \\
\text { BIO Sec. } 5.3 .2 .14 \text {, } \\
\text { Flammable Gas } \\
\text { Deflagrations; } \\
\text { Criteria } 14 .\end{array}$ & sc \\
\hline $\begin{array}{l}\text { Tank Flow } \\
\text { Indication } \\
\text { Instrument } \\
\text { Loop } \\
\text { (Tank Exhaust } \\
\text { Outlet) }\end{array}$ & $\begin{array}{l}\text { FE-AY101K1-2, } \\
\text { FT-AY101K1-2, \& } \\
\text { FIC-AY1Ki-2 } \\
\text { (similar, for } \\
\text { other } 3 \text { tanks; } \\
\text { ref. P\&ID } \\
\text { H-2-131075) }\end{array}$ & $\begin{array}{l}\text { Indicates/verifies } \\
\text { rate of exhaust air } \\
\text { flow from each primary } \\
\text { tank. }\end{array}$ & $\begin{array}{l}\text { Instrument } \\
\text { malfunction, loss } \\
\text { of calibration, } \\
\text { or loss of power } \\
\text { or signal. }\end{array}$ & $\begin{array}{l}\text { Inability to verify system is } \\
\text { performing safety function and } \\
\text { maintaining flowi could lead } \\
\text { to a buildup of flammable. } \\
\text { gases in tank vapor space. }\end{array}$ & $\begin{array}{l}\text { Monitors and supports } \\
\text { safety function of } \\
\text { exhaust fan; Blo sec. } \\
5.3 .2 .14 \text {, Flammable } \\
\text { Gas Deflagrations; } \\
\text { Criteria } 14 .\end{array}$ & $s c$ \\
\hline $\begin{array}{l}\text { Tank Flow } \\
\text { Indication } \\
\text { Ins trument } \\
\text { Loops } \\
\text { (Tank Air } \\
\text { Inlet) }\end{array}$ & $\begin{array}{l}\text { FE-AY101KI-1, } \\
\text { FT-AY } 101 \mathrm{~K} 1-1 \text {, \& } \\
\text { FIC-AY1KI-1 } \\
\text { (similar, for } \\
\text { other } 3 \text { tanks; } \\
\text { ref. P\&ID } \\
\text { H-2-i31075) }\end{array}$ & $\begin{array}{l}\text { Indicates/verifies } \\
\text { rate of fresh air flow } \\
\text { into primary tank (via } \\
\text { air inlet station } \\
\text { only, may not include } \\
\text { all sources of } \\
\text { inflow). }\end{array}$ & $\begin{array}{l}\text { Instrument } \\
\text { mat function, loss } \\
\text { of calibration, } \\
\text { or loss of power } \\
\text { or signal. }\end{array}$ & $\begin{array}{l}\text { Inability to verify system air } \\
\text { flow through normal tank inlet } \\
\text { path; failure does not affect } \\
\text { safety function of system or } \\
\text { flow, as flow is more reliably } \\
\text { monitored at tank outlet. }\end{array}$ & $\begin{array}{l}\text { Can help optimize or } \\
\text { moni tor performance of } \\
\text { air inlet stations, } \\
\text { but not necessary for } \\
\text { function. }\end{array}$ & GS \\
\hline $\begin{array}{l}\text { Damper Limit } \\
\text { Switches, all } \\
\text { manual and } \\
\text { motor-operate } \\
\text { d dampers } \\
\text { (ref. P\&IDs) }\end{array}$ & $\begin{array}{l}\text { "Zs-1" or } \\
\text { "ZT-/ZI-" } \\
\text { various (ref. } \\
\text { P\&IDs, incl. } \\
\text { bypass \& } \\
\text { recirc. l ines; } \\
\text { located with } \\
\text { dampers) }\end{array}$ & $\begin{array}{l}\text { Indicates damper } \\
\text { positions. }\end{array}$ & $\begin{array}{l}\text { Instrument } \\
\text { mal function, loss } \\
\text { of cat ibration, } \\
\text { or loss of power } \\
\text { or signat. }\end{array}$ & $\begin{array}{l}\text { Loss of signal verifying } \\
\text { positions of dampers routing } \\
\text { primary flow path. }\end{array}$ & $\begin{array}{l}\text { Failure would not } \\
\text { affect safety function } \\
\text { of system, as there } \\
\text { are alternate means of } \\
\text { verifying valve } \\
\text { lineup. }\end{array}$ & GS \\
\hline $\begin{array}{l}\text { HEME } \\
\text { Radiation } \\
\text { Monitor }\end{array}$ & RIAS-AZK109-1 & $\begin{array}{l}\text { Indicates radioactive } \\
\text { inventory of HEME; } \\
\text { used to indicate need } \\
\text { for HEME changeout. }\end{array}$ & $\begin{array}{l}\text { Instrument } \\
\text { mal funct ion, loss } \\
\text { of cal ibration, } \\
\text { or loss of power } \\
\text { or signal. }\end{array}$ & $\begin{array}{l}\text { Inability to changeout HEME on } \\
\text { a timely basis as required by } \\
\text { TSR Administrative control. }\end{array}$ & $\begin{array}{l}\text { TSR AC } 5.18 \text {, HEPA } \\
\text { Filter Controls; BIO } \\
\text { Sec. } 5.3 .2 .2 \text {, HEPA } \\
\text { Filter Failure; } \\
\text { Criteria 4. }\end{array}$ & SS \\
\hline
\end{tabular}


Table A-1. Active Ventilation for 241-AY/AZ, Project W-030 Ventilation Upgrade. (11 Sheets)

\begin{tabular}{|c|c|c|c|c|c|c|}
\hline \multicolumn{2}{|c|}{ SYSTEM, STRUCTURE, OR COMPONENT } & \multirow{2}{*}{ SAFETY FUNCTION(S) } & \multirow{2}{*}{ FAILURE MODE } & \multirow{2}{*}{$\begin{array}{l}\text { EFFECT OF FAILURE ON SAFETY } \\
\text { FUNCTION }\end{array}$} & \multirow{2}{*}{$\begin{array}{l}\text { JUSTIFICATION FOR } \\
\text { SAFETY CLASSIFICATION }\end{array}$} & \multirow{2}{*}{$\begin{array}{l}\text { SAFETY } \\
\text { CLASS* }\end{array}$} \\
\hline DEESCRIPTION & $\begin{array}{l}\text { IDENTIFICATION } \\
\text { NO. }\end{array}$ & & & & & \\
\hline $\begin{array}{l}\text { Temperature } \\
\text { Indic. Instr. } \\
\text { Loops, before } \\
\text { and after } \\
\text { Primary } \\
\text { Heaters and } \\
\text { Filters (ref. } \\
\text { H-2-131076) }\end{array}$ & $\begin{array}{l}\text { TE-AZK102-1A, } \\
\text { TE-AZK102-1A1, } \\
\text { TT-AZK102-1A, } \\
\text { TI-AZK12-1A, } \\
\text { TDIC-AZK12-1A, } \\
\text { TIC-AZK102-1A, } \\
\text { etc. ( } \text { ( imilar, } \\
\text { for 'B' train) }\end{array}$ & $\begin{array}{l}\text { Helps protect } \\
\text { integrity of primary } \\
\text { filters by monitoring } \\
\text { and controlling heater } \\
\text { function, and } \\
\text { preventing high } \\
\text { temperature at filter } \\
\text { face. }\end{array}$ & $\begin{array}{l}\text { Instrument } \\
\text { mal function, loss } \\
\text { of cal ibration, } \\
\text { or loss of power } \\
\text { or signal. }\end{array}$ & $\begin{array}{l}\text { Inability to verify airstream } \\
\text { temperature at filter face; } \\
\text { disabl ing of automatic high } \\
\text { temperature heater shutdown; } \\
\text { could result in failure of } \\
\text { primary HEPA/HEGA filters. }\end{array}$ & $\begin{array}{l}\text { Failure has no } \\
\text { immediate effect on } \\
\text { flow or confinement; } \\
\text { CAM interlock and } \\
\text { diff. pressure } \\
\text { instruments initiate } \\
\text { corrective actions. }\end{array}$ & GS \\
\hline $\begin{array}{l}\text { Temperature } \\
\text { Indic. Instr. } \\
\text { Loop, before } \\
\text { and after } \\
\text { Primary } \\
\text { Condenser }\end{array}$ & $\begin{array}{l}\text { TE-AZK108-1A1, } \\
\text { IE-AZK108-1A2, } \\
\text { TI-AZK108-1A, } \\
\text { TI-AZK18-1A, } \\
\text { TE-AZK108-1B1, } \\
\text { TE-AZK108-1B2, } \\
\text { TT-AZK108-1B, } \\
\text { TI-AZK18-1B }\end{array}$ & $\begin{array}{l}\text { Monitors or verifies } \\
\text { proper function of } \\
\text { condenser; indication } \\
\text { only. }\end{array}$ & $\begin{array}{l}\text { Instrument } \\
\text { mal function, loss } \\
\text { of cal ibration, } \\
\text { or loss of power } \\
\text { or signal. }\end{array}$ & $\begin{array}{l}\text { Inability to monitor or verify } \\
\text { equipment performance; could } \\
\text { result in reduced system } \\
\text { operating efficiency. }\end{array}$ & $\begin{array}{l}\text { Helps optimize } \\
\text { performance of } \\
\text { equipment but not } \\
\text { necessary for safety } \\
\text { function. }\end{array}$ & GS \\
\hline $\begin{array}{l}\text { Temperature } \\
\text { Indic. Instr. } \\
\text { Loop, after } \\
\text { Tank Air } \\
\text { Inlet Heater }\end{array}$ & $\begin{array}{l}\text { TIC-AY } 101 \times 102-1 \\
\text { IAL-AYK12-1 } \\
\text { (similar, for } \\
\text { other } 3 \text { tanks; } \\
\text { ref. P\&ID } \\
\text { H-2-131075) }\end{array}$ & $\begin{array}{l}\text { Monitors temperature } \\
\text { at face of air inlet } \\
\text { filter; controls } \\
\text { heater and actuates } \\
\text { alarm. }\end{array}$ & $\begin{array}{l}\text { Instrument } \\
\text { mal function, loss } \\
\text { of calibration, } \\
\text { or loss of power } \\
\text { or signal. }\end{array}$ & $\begin{array}{l}\text { Inability to yerify airstream } \\
\text { temperature at filter face; } \\
\text { disabling of automatic high } \\
\text { temperature heater shutdown; } \\
\text { could result in failure of } \\
\text { inlet HEPA filter. }\end{array}$ & $\begin{array}{l}\text { Supports a general } \\
\text { service component. }\end{array}$ & GS \\
\hline $\begin{array}{l}\text { Temperature } \\
\text { Indic. Instr. } \\
\text { Loop, before } \\
\text { and after } \\
\text { Recirc. } \\
\text { Condenser } \\
\text { (ref. P\&IDs } \\
\mathrm{H}-2-131062-\mathrm{H}- \\
2-131065 \text { ) }\end{array}$ & $\begin{array}{l}\text { TE-AY101K408-1A } \\
\text { TI-AY101K408-1A } \\
\text { TE-AY101K408-1B } \\
\text { TI-AY101K408-1B } \\
\text { TE-AY101EWS-1 } \\
\text { TI-AY1EWS-1 } \\
\text { TE-AY101EWR-1 } \\
\text { TE-AY1EWR-1 } \\
\text { (simi lar, for } \\
\text { other } 3 \text { tanks) }\end{array}$ & $\begin{array}{l}\text { Monitors or verifies } \\
\text { proper function of } \\
\text { recirc. condenser; } \\
\text { indication only. }\end{array}$ & $\begin{array}{l}\text { Instrument } \\
\text { malfunction, loss } \\
\text { of calibration, } \\
\text { or loss of power } \\
\text { or signal. }\end{array}$ & $\begin{array}{l}\text { Inability to monitor or verify } \\
\text { equipment performance; could } \\
\text { result in reduced system } \\
\text { operating efficiency. }\end{array}$ & $\begin{array}{l}\text { Helps optimize } \\
\text { performance of } \\
\text { equipment but not } \\
\text { necessary for safety } \\
\text { function. } \\
\text {. }\end{array}$ & GS \\
\hline $\begin{array}{l}\text { Pressure } \\
\text { Instrument } \\
\text { Loops, } \\
\text { Primary HEPA } \\
\text { \& HEGA } \\
\text { Filters (ref. } \\
\text { H-2-131076) }\end{array}$ & $\begin{array}{l}\text { PDT-AZK104-1A, } \\
\text { PDT-AZK104-2A, } \\
\text { PDT-AZK110-1A, } \\
\text { PDI-AZK14-1A,' } \\
\text { PDI-AZK110-1A, } \\
\text { PDI-AZK14-2A' } \\
\text { (similar, for } \\
\text { 'B' train) }\end{array}$ & $\begin{array}{l}\text { Helps protect } \\
\text { integrity of primary } \\
\text { filters by monitoring } \\
\text { pressure drop across } \\
\text { filters and initiating } \\
\text { corrective action in } \\
\text { the event of high or } \\
\text { low diff. pressure. }\end{array}$ & $\begin{array}{l}\text { Instrument } \\
\text { malfunction, loss } \\
\text { of calibration, } \\
\text { or loss of power } \\
\text { or signal. }\end{array}$ & $\begin{array}{l}\text { Inability to verify pressure } \\
\text { drop across HEPA and HEGA } \\
\text { filters; disabling of } \\
\text { automatic high diff. pressure } \\
\text { shutdown; could result in } \\
\text { failure of primary HEPA/HEGA } \\
\text { filters and onsite release. }\end{array}$ & $\begin{array}{l}\text { Failure affects onsite } \\
\text { worker safety; a } \\
\text { compensatory measure } \\
\text { in lieu of cAM } \\
\text { interlock to initiate } \\
\text { corrective action in } \\
\text { the event of a filter } \\
\text { breach; BIo } \\
\text { Sec. } 5.3 .2 .2 \text {; } \\
\text { Criteria } 12 \text {. }\end{array}$ & ss \\
\hline
\end{tabular}


Table A-1. Active Ventilation for 241-AY/AZ, Project W-030 Ventilation Upgrade. (11 Sheets)

\begin{tabular}{|c|c|c|c|c|c|c|}
\hline \multicolumn{2}{|c|}{ SYSTEM, STRUCTURE, OR COMPONENT } & \multirow{2}{*}{ SAFETY FUNCTION(S) } & \multirow{2}{*}{ FAILURE MODE } & \multirow{2}{*}{$\begin{array}{l}\text { EFFECT OF FAILURE ON SAFETY } \\
\text { FUNCTION }\end{array}$} & \multirow{2}{*}{$\begin{array}{l}\text { JUSTIFICATION FOR } \\
\text { SAFETY CLASSIFICATION }\end{array}$} & \multirow{2}{*}{$\begin{array}{l}\text { SAFETY } \\
\text { CLASS }\end{array}$} \\
\hline DESCRIPTION & $\begin{array}{l}\text { IDENTIFICATION } \\
\text { NO. }\end{array}$ & & & & & \\
\hline $\begin{array}{l}\text { Pressure } \\
\text { Instrument } \\
\text { Loop, HEME }\end{array}$ & $\begin{array}{l}\text { PDT-AZK109-1, } \\
\text { PDI-AZK19-1 }\end{array}$ & $\begin{array}{l}\text { Monitors or verifies } \\
\text { proper function of } \\
\text { HEME; alarms on high } \\
\text { diff. pressure. }\end{array}$ & $\begin{array}{l}\text { Instrument } \\
\text { mal function, loss } \\
\text { of calibration, } \\
\text { or loss of power } \\
\text { or signal. }\end{array}$ & $\begin{array}{l}\text { Inability to verify pressure } \\
\text { drop across HEME; disabling of } \\
\text { alarm function. }\end{array}$ & $\begin{array}{l}\text { Helps optimize } \\
\text { performance of } \\
\text { equipment but not } \\
\text { necessary for safety } \\
\text { function; HEME may be } \\
\text { bypassed. }\end{array}$ & GS \\
\hline $\begin{array}{l}\text { Pressure } \\
\text { Instruntent } \\
\text { Loop, Primary } \\
\text { Condenser }\end{array}$ & $\begin{array}{l}\text { PDT-AZK108-1, } \\
\text { PDI-AZK18-1 }\end{array}$ & $\begin{array}{l}\text { Monitors or verifies } \\
\text { proper function of } \\
\text { condenser; alarms on } \\
\text { high diff. pressure. }\end{array}$ & $\begin{array}{l}\text { Instrument } \\
\text { mal function, loss } \\
\text { of calibration, } \\
\text { or loss of power } \\
\text { or signal. }\end{array}$ & $\begin{array}{l}\text { Inability to verify pressure } \\
\text { drop across condenser; } \\
\text { disabling of alarm function. }\end{array}$ & $\begin{array}{l}\text { Helps optimize } \\
\text { performance of } \\
\text { equipment but not } \\
\text { necessary for safety } \\
\text { function; condenser } \\
\text { may be bypassed. }\end{array}$ & GS \\
\hline $\begin{array}{l}\text { Pressure } \\
\text { Instrument } \\
\text { Loops, Tank } \\
\text { Air Inlet } \\
\text { Filters }\end{array}$ & $\begin{array}{l}\text { PDI -AY } 101 \mathrm{~K} 103-1 \\
\text { POI-AY101K104-1 } \\
\text { PDIS-AY101K1-1 } \\
\text { (simi lar, for } \\
\text { other } 3 \text { tanks; } \\
\text { ref. P\&ID } \\
\text { H-2-131075) }\end{array}$ & $\begin{array}{l}\text { Helps protect } \\
\text { integrity of air inlet } \\
\text { filters by monitoring } \\
\text { pressure drop across } \\
\text { filters and initiating } \\
\text { corrective action in } \\
\text { the event of high or } \\
\text { low diff. pressure. }\end{array}$ & $\begin{array}{l}\text { Instrument } \\
\text { mal function, loss } \\
\text { of calibration, } \\
\text { or loss of power } \\
\text { or signal. }\end{array}$ & $\begin{array}{l}\text { Inability to verify pressure } \\
\text { drop across inlet HEPA filter; } \\
\text { disabling of alarm; could } \\
\text { result in failure of inlet } \\
\text { HEPA filter and loss of } \\
\text { confinement (only if } \\
\text { concurrent with a tank } \\
\text { pressurization). }\end{array}$ & $\begin{array}{l}\text { Not necessary for } \\
\text { safety function. }\end{array}$ & GS \\
\hline $\begin{array}{l}\text { Pressure } \\
\text { Instrument } \\
\text { Loops, } \\
\text { Recirc. } \\
\text { Moisture } \\
\text { Separators } \\
\text { and } \\
\text { Condensers }\end{array}$ & $\begin{array}{c}\text { PDE-AY101K405-1 } \\
\text { PDT-AY101K405-1 } \\
\text { PDI-AY1K45-1, } \\
\text { PDE-AY101K408-1 } \\
\text { PDT-AY101K408-1 } \\
\text { PDI-AY1K48-1 } \\
\text { (similar, for } \\
\text { other } 3 \text { tanks; } \\
\text { ref. P\&IDs } \\
\text { H-2-131062-H-2- } \\
131065 \text { ) }\end{array}$ & $\begin{array}{l}\text { Monitors or verifies } \\
\text { proper function of } \\
\text { condenser; alarms on } \\
\text { high diff. pressure. }\end{array}$ & $\begin{array}{l}\text { Instrument } \\
\text { malfunction, loss } \\
\text { of calibration, } \\
\text { or loss of power } \\
\text { or signal.. }\end{array}$ & $\begin{array}{l}\text { Inability to monitor or verify } \\
\text { equipment performance; could } \\
\text { result in reduced system } \\
\text { operating efficiency. }\end{array}$ & $\begin{array}{l}\text { Helps opt imize } \\
\text { performance of } \\
\text { equipment but not } \\
\text { necessary for safety } \\
\text { function. }\end{array}$ & GS \\
\hline $\begin{array}{l}\text { Leak } \\
\text { detection } \\
\text { instrumentat i } \\
\text { on on duct } \\
\text { encasement } \\
\text { lines, etc. }\end{array}$ & $\begin{array}{l}\text { "LD-" (various, } \\
\text { ref. P\&1D } \\
H-2-131062-H-2- \\
131065 \& \\
H-2-131075 \text { ) }\end{array}$ & $\begin{array}{l}\text { Notifies operator in } \\
\text { the event of a } \\
\text { condensate leak from } \\
\text { ductwork. } \\
\text {. }\end{array}$ & $\begin{array}{l}\text { Instrument. } \\
\text { mal function, loss } \\
\text { of calibration, } \\
\text { or loss of power } \\
\text { or signal. }\end{array}$ & $\begin{array}{l}\text { Inability to monitor or verify } \\
\text { loss of condensate from breach } \\
\text { in ductwork; does not preclude } \\
\text { other means of detecting a } \\
\text { breach in primary ductwork. }\end{array}$ & $\begin{array}{l}\text { Condensate is not a } \\
\text { significant source } \\
\text { term, and not included } \\
\text { in Blo accident } \\
\text { scenarios. }\end{array}$ & GS \\
\hline
\end{tabular}


Table A-1. Active Ventilation for 241-AY/AZ, Project W-030 Ventilation Upgrade. (11 Sheets)

\begin{tabular}{|c|c|c|c|c|c|c|}
\hline \multicolumn{2}{|c|}{ SYSTEM, STRUCTURE, OR COMPONENT } & \multirow[b]{2}{*}{ SAFETY FUNCTION(S) } & \multirow[b]{2}{*}{ FALLURE MODE } & \multirow{2}{*}{$\begin{array}{l}\text { EFFECT OF FAILURE ON SAFETY } \\
\text { FUNCTION }\end{array}$} & \multirow{2}{*}{$\begin{array}{l}\text { JUSTIFICATION FOR } \\
\text { SAFETY CLASSIFICATION }\end{array}$} & \multirow{2}{*}{$\begin{array}{l}\text { SAFETY } \\
\text { CLASS }\end{array}$} \\
\hline DESCRIPTION & $\begin{array}{l}\text { - IDENTIFICATION } \\
\text { NO. }\end{array}$ & & & & & \\
\hline
\end{tabular}

\section{NOTES:}

* $\quad S C=$ Safety Class; $\quad S S=$ Safety Significant; $G S=$ General Service (not safety related). Assignments based on BIO safety analyses and "SSC Criteria" in HNF-PRO-516 (formerly Sec. 9.0 of WHC-CM-4-46, Safety Analyses Manual, Westinghouse Hanford Company, Richland, Washington); see rable 2 in Sec. 3.1, this SEL.

** "SS" classification of buildings is based on Appendix A, para. 3.e of HNF-PRO-516, regarding interaction hazards. Structures housing SC components must be designed to applicable SC seismic, wind, and other natural phenomena design loads, except where it can be shown that interaction hazards to $\mathbf{S C}$ equipment are unlikely or do not adversely affect a safety function.

*** Double-shell tanks (DSTs), including AWF tanks, are not included in the list of Safety Class or Safety significant sSCs in the BIO. The classification of these passive design features as Safety class, Safety significant, or general service will be provided in the TwRS final safety analys is report, or FSAR (ref. BIO, Sec. 2.0) 
Table A-2. Ventilation CAM Interlock for 241-AY/AZ, Project W-030 Ventilation Upgrade. (2 Sheets)

\begin{tabular}{|c|c|c|c|c|c|c|c|c|c|}
\hline \multicolumn{2}{|c|}{ SYSTEM IDENTIFICATION } & \multicolumn{2}{|c|}{ SAFETY FUNCTION(S) } & \multicolumn{2}{|c|}{ FUNCTIONAL REQUIREMENTS } & \multicolumn{2}{|c|}{ CLASSIFICATION } & \multicolumn{2}{|c|}{ JUSTIFICATION } \\
\hline \multicolumn{2}{|c|}{$\begin{array}{l}\text { 241-AY/AZ Tank Farm } \\
\text { Active Ventilation CAM } \\
\text { Interlock System } \\
\text { (located on } 296-A-42 \\
\text { Primary Exhaust Stack), } \\
\text { ref. P\&ID H-2-131078. }\end{array}$} & \multicolumn{2}{|c|}{$\begin{array}{l}\text { Prevents an unfiltered } \\
\text { release from occurring for } \\
\text { more than } 10 \text { minutes }\end{array}$} & \multicolumn{2}{|c|}{$\begin{array}{l}\text { The CAM must operate cont inuously while the } \\
\text { exhaust system is operating, maintaining } \\
\text { isokinetic sampling conditions. The CAM } \\
\text { must measure the radiation level in the } \\
\text { sampled flow stream and detect levels in } \\
\text { excess of a preset level. The CAM shall } \\
\text { activate an interlock to shut down the } \\
\text { exhauster, or switch exhaust trains, within } \\
10 \text { minutes of detecting an excess radiation } \\
\text { level. upon cAM failure, the monitors must } \\
\text { actuate an alarm and an interlock to shut } \\
\text { down the exhaust system. }\end{array}$} & \multicolumn{2}{|l|}{ ss } & $\begin{array}{l}\text { HNF-SD-WM-BIO-00 } \\
\text { (BIO) Sec. } 5.3 .2 \\
\text { Leak in Structur } \\
\text { Overground Waste } \\
\text { Line; Criteria } 1\end{array}$ & $\begin{array}{l}\text { Rev. } 0 \text {, } \\
\text { HEPA } \\
\text { fety SSC } \\
\text { Rev. } 0 \text {, } \\
\text { or Spray } \\
\text { ransfer }\end{array}$ \\
\hline \multicolumn{10}{|c|}{ THE ITEMS LISTED BELOW ARE UNIQUE COMPONENTS THAT MAKE UP THE SAFETY SSC } \\
\hline \multicolumn{3}{|c|}{ SYSTEM, STRUCTURE, OR COMPONENT } & \multirow{2}{*}{ SAFETY FUNCTION(S) } & \multirow{2}{*}{ FALLURE MODE } & \multirow{2}{*}{\multicolumn{2}{|c|}{$\begin{array}{l}\text { EFFECT OF FAILURE ON SAFETY } \\
\text { FUNCTION }\end{array}$}} & \multirow{2}{*}{\multicolumn{2}{|c|}{$\begin{array}{l}\text { JUSTIFICATION FOR } \\
\text { SAFETY CLASSIFICATION }\end{array}$}} & \multirow{2}{*}{$\begin{array}{l}\text { SAFETY } \\
\text { CLASS* }\end{array}$} \\
\hline DESCRIPTION & IDENTI & CATION & & & & & & & \\
\hline $\begin{array}{l}\text { Beta/Gamma } \\
\text { Radioactive } \\
\text { Particulate } \\
\text { Monitor } \\
\text { Instr. Loop } \\
\text { and interlock } \\
\text { to fans }\end{array}$ & \multicolumn{2}{|c|}{$\begin{array}{l}\text { RE-AZK1-1 \& } \\
\text { RIAS-AZK1-1 }\end{array}$} & $\begin{array}{l}\text { Monitors for radiation } \\
\text { in exhaust stream, and } \\
\text { interlocks to shut } \\
\text { down fan }\end{array}$ & $\begin{array}{l}\text { Mal function } \\
\text { caused by } \\
\text { excessive } \\
\text { moisture in } \\
\text { sample line or } \\
\text { high temperature, } \\
\text { loss of } \\
\text { cal ibration. }\end{array}$ & \multicolumn{2}{|c|}{$\begin{array}{l}\text { Failed CAM will not shut down } \\
\text { the active ventilation system } \\
\text { in the event of a failed HEPA } \\
\text { filter, resulting in an } \\
\text { unmonitored, unfiltered } \\
\text { release of radioactive } \\
\text { particulate. }\end{array}$} & \multicolumn{2}{|c|}{$\begin{array}{l}\text { BIo sec. } 5.3 .2 .20 \\
\text { Spray Leak in } \\
\text { structure; Criteria } \\
14 .\end{array}$} & SC \\
\hline Vacuum Pumps & \multicolumn{2}{|c|}{$\begin{array}{c}A Z-K 1-11-1 \& \\
A Z-K 1-11-2\end{array}$} & $\begin{array}{l}\text { Draw sample from } \\
\text { exhaust stream }\end{array}$ & $\begin{array}{l}\text { Failure of motor } \\
\text { due to heating or } \\
\text { loss of power; } \\
\text { mech. failure of } \\
\text { pump. }\end{array}$ & \multicolumn{2}{|c|}{$\begin{array}{l}\text { Loss of sample stream to CAM, } \\
\text { or loss of consistent sample } \\
\text { gas flow rate; failure of CAM } \\
\text { to detect radioactive } \\
\text { particulate and shut down } \\
\text { exhauster in the event of a } \\
\text { HEPA filter failure. }\end{array}$} & \multicolumn{2}{|c|}{$\begin{array}{l}\text { BIo Sec. } 5.3 .2 .20 \\
\text { Spray Leak in } \\
\text { Structure; Criteria } \\
14 .\end{array}$} & sc \\
\hline
\end{tabular}


Table A-2. Ventilation CAM Interlock for 241-AY/AZ, Project W-030 Ventilation Upgrade. (2 Sheets)

\begin{tabular}{|c|c|c|c|c|c|c|}
\hline \multicolumn{2}{|c|}{ SYSTEM, STRUCTURE, OR COMPONENT } & \multirow[b]{2}{*}{ SAFETY FUNCTION(S) } & \multirow[b]{2}{*}{ FAILURE MODE } & \multirow{2}{*}{$\begin{array}{l}\text { EFFECT OF FAILURE ON SAFETY } \\
\text { FUNCTION }\end{array}$} & \multirow{2}{*}{$\begin{array}{l}\text { JUSTIFICATION FOR } \\
\text { SAFETY CLASSIFICATION }\end{array}$} & \multirow{2}{*}{$\begin{array}{l}\text { SAFET } \\
\text { CLASS* }\end{array}$} \\
\hline DESCRIPTION & $\begin{array}{l}\text { IDENTIFICATION } \\
\text { NO. }\end{array}$ & & & & & \\
\hline $\begin{array}{l}\text { Flow Alarm } \\
\text { Switch Instr. } \\
\text { Loop }\end{array}$ & $\begin{array}{l}\text { FE-AZK1-1, } \\
\text { FIT-AZK1-1, } \\
\text { UC-AZK1-2, \& } \\
\text { FAL-AZK1-1A }\end{array}$ & $\begin{array}{l}\text { Senses sample stream } \\
\text { flow rate and atarms } \\
\text { upon low flow }\end{array}$ & $\begin{array}{l}\text { Mechanical or } \\
\text { elec. failure of } \\
\text { switch, Loss of } \\
\text { calibration }\end{array}$ & $\begin{array}{l}\text { Cont intred operation of } \\
\text { ventilation system wi thout CAM } \\
\text { function, failure to shut down } \\
\text { active ventilation in the } \\
\text { event of a failed HEPA filter, } \\
\text { resulting in an unmonitored, } \\
\text { unfiltered release of } \\
\text { radioactive particulate. }\end{array}$ & $\begin{array}{l}\text { Blo Sec. } 5.3 .2 .20 \text {, } \\
\text { Spray Leak in } \\
\text { Structure; Criteria } \\
14 .\end{array}$ & SC \\
\hline $\begin{array}{l}\text { Flow } \\
\text { Regulator } \\
\text { (MOV) }\end{array}$ & $M V-A Z K 1-1$ & $\begin{array}{l}\text { Regulates constant } \\
\text { sample flow through } \\
\text { CAM system }\end{array}$ & $\begin{array}{l}\text { Mechanical or } \\
\text { elec. faiture of } \\
\text { valve actuator }\end{array}$ & $\begin{array}{l}\text { Failure of regulator is } \\
\text { normally detected by the flow } \\
\text { alarm switch, resulting in } \\
\text { corrective action to restore } \\
\text { system to operation. }\end{array}$ & $\begin{array}{l}\text { Flow alarm switch } \\
\text { provides safety } \\
\text { function; failure of } \\
\text { regulator will not } \\
\text { affect safety function } \\
\text { of system. }\end{array}$ & GS \\
\hline \multicolumn{7}{|c|}{ NOTE: $\quad}$. \\
\hline \multicolumn{7}{|c|}{$\begin{array}{l}\text { SC = Safety Class; SS = Safety Significant; GS = General Service (not safety related). Assignments based BIO analyses and "SSC Criteria" } \\
\text { in HNF-PRO-516 (formerly Sec. } 9.0 \text { of WHC-CM-4-46, Safety Analyses Manual, West inghouse Hanford Company, Richland, Washington); see Table } 2 \\
\text { in Sec. 3.1, this SEL. }\end{array}$} \\
\hline
\end{tabular}


HNF-1788 Rev, O

APPENDIX B

SAFETY CLASS UPGRADE SUMMARY TABLE 
SAFETY CLASS UPGRADE SUMMARY TABLE

\begin{tabular}{|c|c|c|c|c|c|}
\hline \multirow{2}{*}{$\begin{array}{l}\text { EQUIPMENT } \\
\text { IDENTIFICATION } \\
\text { NUMBER }\end{array}$} & \multirow{2}{*}{ DESCRIPTION } & \multirow{2}{*}{ SPECIFICATION } & \multicolumn{2}{|c|}{ CLASSIFICATION } & \multirow{2}{*}{ COMMENTS } \\
\hline & & & $\begin{array}{l}\text { Required } \\
\text { per Blo }\end{array}$ & MEETS & \\
\hline $241-A Z-702$ & Ventilation Building & W-030-C2 & ss & GS* & $\begin{array}{l}\text { Designed to SS loads, procured to GS } \\
\text { requi rements. Cert. of Compl iance (COC) in } \\
\text { vendor submittal } 85 \text {; design anal. in } \\
\text { submi ttal } 162 \text {. } \\
\text { *See also discussion, Sec. } 3.0 \& 4.0 \text {. }\end{array}$ \\
\hline $241-\mathrm{AZ}-701$ & Generator Building & & ss & GS* & $\begin{array}{l}\text { Designed to SS loads, procured to GS } \\
\text { requirements. Design anal. in vendor } \\
\text { sulsmittal } 162 \text {. } \\
\text { *see also discussion, sec. } 3.0 \& 4.0 \text {. }\end{array}$ \\
\hline $\begin{array}{l}241-A Y-401 \\
241-A Y-402 \\
241, A Z-401 \\
241-A Z-402\end{array}$ & Recirculation and Cooling Cell Bldgs. & & ss & GS* & $\begin{array}{l}\text { Designed to sS loads, procured to GS } \\
\text { requirements. } \\
\text { *See also discussion, Sec. } 3.0 \& 4.0 \text {. }\end{array}$ \\
\hline $\begin{array}{l}\text { MK-AY101K1-1 } \\
\text { MK-AY102K1-1 } \\
\text { MK-AZ101K1-1 } \\
\text { MK-AZ102K1-1 } \\
\text { Ducting } \\
\text { Housings } \\
\text { Struct. Frame } \\
\text { Base }\end{array}$ & $\begin{array}{l}\text { Primary tank vent system Air Inlet Stations } \\
\text { Pressure Control valves. Butterfly, 6", } \\
\text { electrically operated. } \\
\text { Tubing, ASTM A269, } 304 \\
\text { Sheet, 12 Ga. SST ASTM } 2240304 \\
\text { Channel, ASTM A36, CS } \\
\text { Channel, ASTM A36, CS } \\
\text { The above components were supplied with the } \\
\text { four Air Inlet Stations designed and built } \\
\text { vendor; refer to cVI } \$ 22525 \text {, supp } 98 \text {. }\end{array}$ & $W-030-P 5$ & sc & $\mathrm{sc}$ & $\begin{array}{l}\text { *See discussion of valves, Sec. } 3.0 \& 4.0 \text {. } \\
\text { Entire air inlet station procured and } \\
\text { qualified per spec. as an assembled unit. } \\
\text { coc from vendor in cVII\#22525, Supp. } 94 \text {, } \\
\text { stating all requirements of spec. have been } \\
\text { met. CMTRs for the steel used to fabricate } \\
\text { the stations are in cVI\#22525, Supp } 94 \text {, } \\
\text { design analysis in cVI } \$ 22525 \text {, supp } 91 \text {. }\end{array}$ \\
\hline
\end{tabular}




\begin{tabular}{|c|c|c|c|c|c|}
\hline \multirow{2}{*}{$\begin{array}{l}\text { EQUIPMENT } \\
\text { IDENTIFICATION } \\
\text { NUMBER }\end{array}$} & \multirow{2}{*}{ DESCRIPTION } & \multirow{2}{*}{ SPECIFICATION } & \multicolumn{2}{|c|}{ CLASSIFICATION } & \multirow{2}{*}{ COMMENTS } \\
\hline & & & $\begin{array}{l}\text { Required } \\
\text { per BlO }\end{array}$ & MEETS & \\
\hline $\begin{array}{l}V-A Y 1100-M 9 \\
V-A Y 2100-M 9 \\
V-A Z 1100-M 9 \\
V-A Z 2100-M 9\end{array}$ & $\begin{array}{l}\text { Primary tank vent system } \\
\text { Piping into the waste tanks from the Air } \\
\text { Inlet Stations. }\end{array}$ & $W-030-C 3$ & sc & sc & $\begin{array}{l}\text { CMTRs from qualified suppliers in vendor } \\
\text { sulanittal } 5 \text {. }\end{array}$ \\
\hline $\begin{array}{l}\text { V-AY1101-M9 } \\
\text { V-AY2101-M9 } \\
\text { V-AZ1101-M9 } \\
\text { VAZ2101-M9 } \\
\text { V-AY1102-M9 } \\
\text { V-AZ2102-M9 } \\
\text { V-AZ100-M9 }\end{array}$ & $\begin{array}{l}\text { Piping out of waste tanks (bypass mode) from } \\
\text { recirculation vent cooling modules. } \\
\text { Pipe: Sched } 40 \text { S, SST ASTM A312 Gr TP } 304 \mathrm{~L} \text {. } \\
\text { Fittings: SST ASME SA } 403 \text { Class WP-S } 304 \mathrm{~L} \text {. } \\
\text { See pipe code M-9 of } W-030-C 3 \text {, Section } 15493 \text {. }\end{array}$ & & Sc & sc & . \\
\hline V-AZ103-M9 & $\begin{array}{l}\text { Cell piping (condenser and HEME bypassed). } \\
\text { Pipe: sched } 40 \text {, SST ASTM A312 TP } 304 L \text {. } \\
\text { Fittings: SST ASTM A403 WP } 304 \text { L. } \\
\text { Flanges: CL } 150 \text { F Forged SST ASTM A182 F304L. } \\
\text { See pipe code M-9 of W-030-C2, Section } 15493 \text {. }\end{array}$ & $W-030-c 2$ & sc & sc & $\begin{array}{l}\text { CMTRs from qualified supplier in vendor } \\
\text { submittal } 130 .\end{array}$ \\
\hline $\begin{array}{l}\text { Hangers } \\
\text { Supports }\end{array}$ & See Para. 2.2.9, Sec. $15500, w-030-\mathrm{C} 2$ & & sc & $\mathrm{GS}^{*}$ & $\begin{array}{l}\text { Procured GS; no documentation to show that } \\
\text { hangers and supports meet SC procurement } \\
\text { requirements. } \\
\text { *See discussion of hangers and supports, } \\
\text { Sec. } 3.0 \& 4.0 \text {. }\end{array}$ \\
\hline $\begin{array}{l}\text { MK-AZK108-1C } \\
\text { MK-AZK109-1C }\end{array}$ & $\begin{array}{l}\text { Cell valving (condenser and HEME bypassed). } \\
\text { Butterfly, } 10 \text { ", wafer style, } C L \text {, } 150 \text { NST } \\
\text { body, stem and disc, bubble tight. Remote } \\
\text { operator. } \\
\text { See pipe code } M-9 \text { of } W-030-c 2 \text {, section } 15493 \text {. }\end{array}$ & $W-030-C 2$ & sc. & $\mathrm{SS}^{*}$ & $\begin{array}{l}\text { Coc from the prime contractor for constr. } \\
\text { spec. for valve bodies and bonnets, in } \\
\text { submittal } 132 \text {. }\end{array}$ \\
\hline $\begin{array}{l}\text { MKK-AZK108-1A } \\
\text { KKK-AZK108-1B } \\
\text { MK-AZK109-1A } \\
\text { MK-AZK 109-1B }\end{array}$ & $\begin{array}{l}\text { Cell isolation valving (condenser and HEME } \\
\text { bypassed). } \\
\text { Butterfly, 10", wafer style, CL 150\# SST } \\
\text { body, stem and disc, bubble tight. Remote } \\
\text { operator. } \\
\text { See pipe code M-9 of } \mathrm{W}-030-\mathrm{C2} \text {, section } 15493 \text {. }\end{array}$ & & sc & $s s^{*}$ & $\begin{array}{l}\text { Coc from prime constr. contractor, } \\
\text { sub. } 132 \text {. Meets intent of original ss, } \\
\text { providing conf inement. } \\
\text { * See discussion of valves, sec. } 3.0 \& 4.0 \text {. }\end{array}$ \\
\hline
\end{tabular}




\begin{tabular}{|c|c|c|c|c|c|}
\hline \multirow{2}{*}{$\begin{array}{l}\text { EQUIPMENT } \\
\text { IDENTIFICATION } \\
\text { NUMBER }\end{array}$} & \multirow{2}{*}{ DESCRIPTION } & \multirow{2}{*}{ SPECIFICATION } & \multicolumn{2}{|c|}{ CLASSIFICATION } & \multirow{2}{*}{ COMMENTS } \\
\hline & & & $\begin{array}{l}\text { Required } \\
\text { per Blo }\end{array}$ & MEETS & \\
\hline $\begin{array}{l}\text { FE-AY101K1-2, } \\
\text { FT-AY101K1-2, \& } \\
\text { FIC-AY1K1-2, } \\
\text { (similar, for } \\
\text { other } 3 \text { tanks; } \\
\text { ref. P\&ID } \\
\text { H-2-131075) }\end{array}$ & $\begin{array}{l}\text { Tank Air Flow Indication \& Control Instrument } \\
\text { Loop (Tank Exhaust Out let); incl. flow } \\
\text { indicator controllers, located in local } \\
\text { control units (LCUs) } 1 \text { \& } 2, \mathrm{E} / 1 \text { Rooms, Bldg. } \\
\text { 241-AZ-702: }\end{array}$ & $\begin{array}{l}\text { W- } 030-P 27 \& \& \\
\text { WHC-S-4013 }\end{array}$ & sc. & ss* & $\begin{array}{l}\text { Instrument loops use interface with MCS and } \\
\text { also provide local readout independently of } \\
\text { MCS. LCU cabinets and instruments } \\
\text { qual ified to SS. QAP in submittal } 5 \text {, } \\
\text { Eviron. \& seismic qualification doc. in } \\
\text { cVI } \$ 22525 \text { supp. } 48 \text {. } \\
\text { * See discussion, Sec. } 3.0 \& 4.0 \text {. }\end{array}$ \\
\hline $\begin{array}{l}\text { RE-AZK109-1 \& } \\
\text { RIAS-AZK109-1 }\end{array}$ & HEME Radiation Monitor Instrument Loop & $W-030-P 25$ & ss & GS $^{*}$ & $\begin{array}{l}\text { Instruments depend on interface with MCS to } \\
\text { perform SS safety function per BIO. System } \\
\text { was procured to GS, with GS (UBC) seismic } \\
\text { requirements. Certificate of calibration } \\
\text { in cVIIt22525, Supp. } 69 . \\
\text { *See discussion, Sec. } 3.0 \& 4.0 \text {. }\end{array}$ \\
\hline $\begin{array}{l}V-A Z 105-M 9 \\
V-A Z 102-D 3^{*} \\
V-A Z 103-D 3^{*} \\
V-A Z 106-D 3 \\
V-A Z 107-D 3 \\
V-A Z 108-D 3 \\
V-A Z 109-D 3\end{array}$ & $\begin{array}{l}\text { Primary tank vent system, Filter Train piping } \\
\text { See pipe code M-9, Sec. } 15493 . \\
\text { Duct: Sched } 105, \text { SST ASTM A312 IP } 304 L \text {. } \\
\text { Fittings: SST ASTM A403 Class CR } 304 \text {. } \\
\text { Flanges: SL ip-on, light weight, SST } \\
\text { See duct code D-3 of W-030-C2, Section } 15500 .\end{array}$ & $w-030-c 2$ & $\begin{array}{l}\text { sc } \\
\text { sc }\end{array}$ & $\begin{array}{c}\mathrm{SC} \\
\mathrm{GS}^{*} / \mathrm{SC}\end{array}$ & $\begin{array}{l}\text { CMTRs in vendor submittal } 130 \text {. } \\
\text { No CMTRs for sched } 10 \text { materials. } \\
\text { * Ductwork upstream of filters (V-Az102 \& } \\
\text { V-Az103) procured } S S \text { as part of filter } \\
\text { train piping, per W-030-P3; remaining } \\
\text { ductwork, downstream of filters, outside } \\
\text { conf inement boundary, procured GS. See } \\
\text { also discussion, Sec. } 3.0 \& 4.0 \text {. }\end{array}$ \\
\hline $\begin{array}{l}\text { Ducting } \\
\text { Housing } \\
\text { Support Frame } \\
\text { MK-AZK1-1A } \\
\text { MK-AZK1-1B } \\
\text { MK-AZK1-2A } \\
\text { MK-AZK1-2B } \\
\text { MK-AZK105-1A1 } \\
\text { MK-AZK105-1B1 }\end{array}$ & $\begin{array}{l}\text { Primary tank vent system, Filter Trains } \\
300 \text { series sst } \\
\text { Cs, ASTM A36 } \\
\text { Valve, butterfly, 10", flanged, CL. 150\# SSI } \\
\text { with electric actuators. } \\
\text { 10" Butterfly valves, sSi, manually operated. }\end{array}$ & $W-030-83$ & $\begin{array}{l}\mathrm{sc} \\
\mathrm{sc} \\
\mathrm{sc}\end{array}$ & $\begin{array}{l}\text { sc } \\
\text { sc } \\
\text { ss* }^{*}\end{array}$ & $\begin{array}{l}\text { *See discussion on valves, Sec. } 3.0 \& 4.0 \text {. } \\
\text { Two filter trains procured as unit } \\
\text { assemblies W/ vendor certified } \\
\text { documentation. CVI } 22525 \text {, supp. } 113 \\
\text { contains coc from vendor stating all } \\
\text { requirements of } W-030-P 3 \text { have been met, } \\
\text { also separate cocs for valves, CMTRs for } \\
\text { ducting, housing and frame materials. } \\
\text { Vendor submittal } 6 \text { contains leak test data. } \\
\text { Filter train valves meet intent of original } \\
\text { SS, based on confinement. }\end{array}$ \\
\hline
\end{tabular}




\begin{tabular}{|c|c|c|c|c|c|}
\hline \multirow{2}{*}{$\begin{array}{l}\text { EQUIPMENT } \\
\text { IDENTIFICATION } \\
\text { NUMBER }\end{array}$} & \multirow{2}{*}{ DESCRIPTION } & \multirow{2}{*}{ SPECIFICATION } & \multicolumn{2}{|c|}{ CLASSIFICATION } & \multirow{2}{*}{ - COMMENTS } \\
\hline & & & $\begin{array}{l}\text { Required } \\
\text { per Blo }\end{array}$ & MEETS & \\
\hline $\begin{array}{l}\text { MK-AZK1-3A } \\
\text { MK-AZK1-3B } \\
\text { MK-AZK105-1A2 } \\
\text { MK-AZK105-1B2 }\end{array}$ & $\begin{array}{l}\text { Valving downstream from the filter trains. } \\
\text { 10" butterfly, SST, Manual operators. }\end{array}$ & $\mathrm{W}-030-\mathrm{C} 2$ & sc & GS* & $\begin{array}{l}\text { * See also discussion on valves, Sec. } 3.0 \& \\
4.0 \text {. } \\
\text { Downstream valving is outside confinement } \\
\text { boundary, procured GS per } \mathrm{W}-030-\mathrm{C} 2 \text {. }\end{array}$ \\
\hline $\begin{array}{l}A Z-K 1-5-1 A, \\
A Z-K 1-5-1 B\end{array}$ & $\begin{array}{l}\text { Primary Exhaust Fans: centrifugal type, } \\
0-1000 \text { ScFM. }\end{array}$ & $w-030-P 3$ & sc & sc & $\begin{array}{l}\text { Each fan procured and qualified as part of } \\
\text { an assembly, with filter train; Coc, cMTRs, } \\
\text { and test data for primary fans and drives } \\
\text { in submittal } 6 \text { or } \mathrm{CV1} \# 22525 \text {, Supp. } 113 \text {. }\end{array}$ \\
\hline $\begin{array}{l}\text { VSD }-1 \\
\text { VSD }-2\end{array}$ & Variable frequency drives. & $\mathrm{W}-030-\mathrm{P3}$ & sc & sc & $\begin{array}{l}\text { See comments for primary fans, above } \\
\text { Seismic qualification to } 0.50 \mathrm{~g} \text { a } 3-100 \mathrm{~Hz} \\
\text { in CVI } \# 22525 \text {, Supp. } 113 \text {. }\end{array}$ \\
\hline $\begin{array}{l}\text { PDT -AZK104-1A } \\
\text { PDT-AZK104-2A } \\
\text { PDT-AZK110-1A } \\
\text { PDI-AZK14-1A } \\
\text { PDI-AZK14-2A } \\
\text { PDI-AZK110-1A } \\
\text { (similar, for } \\
\text { 'B train) }\end{array}$ & $\begin{array}{l}\text { Pressure Instrument Loops, Primary HEPA \& } \\
\text { HEGA Filters (ref. H-2-131076) }\end{array}$ & $W-030-P 3$ & $s c^{*}$ & $\$ S^{*}$ & $\begin{array}{l}\text { Procured and qualified with filter train, } \\
\text { as part of overall assembly. } \\
\text { Instruments depend on interface with MCs to } \\
\text { perform safety function; LCU cabinets and } \\
\text { instruments qual ified to sS per original } \\
\text { requirements; see cvitt22525, supp. } 113 \text {. } \\
\text { * Required as a compensatory measure, per } \\
\text { rSRs; see also discussion, Sec. } 3.0 \text { \& } 4.0 \text {. }\end{array}$ \\
\hline $\begin{array}{l}\text { V-AY1200-M9 } \\
\text { VAY2200-M9 } \\
\text { V-AZ1200-M9 } \\
\text { V-AZ2200-M9 } \\
\text { V-AY1203-M9 } \\
V-A Y 2203-M 9 \\
\text { VAZ1203-M9 } \\
V-A Z 2203-M 9\end{array}$ & $\begin{array}{l}\text { Recirculation vent cooling modules. } \\
\text { Piping out of tanks (bypass mode). } \\
\text { Pipe: Sched } 40 S \text {, SST ASTM A312 IP } 304 \mathrm{~L} \text {. } \\
\text { Fittings: SST ASTM A403 WP } 304 \mathrm{~L} \text {. } \\
\text { Flanges: CL } 150 \mathrm{H} \text { Forged SST ASTM A182 F304L } \\
\text { Gaskets and expansion joints may be CGI W/ } \\
\text { cOCs and QC inspection on receipt. } \\
\text { See pipe code M-9 of } W-030-C 2\end{array}$ & $\mathrm{~W}-030-\mathrm{C} 2$ & sc & sc & $\begin{array}{l}\text { CMTRs from qualified suppliers in submittal } \\
130 \text {. coc from the prime contractor for } \\
\text { this constr. specification, in submittal } \\
132 \text {. }\end{array}$ \\
\hline $\begin{array}{l}\text { Hangers } \\
\text { Supports }\end{array}$ & $\begin{array}{l}\text { See Para. 2.2.1.3, Section 15493: } \\
\text { "Pipe supports and attachments ....may be } \\
\text { noncertified material provided material bears } \\
\text { type identifying mark, is suitable for } \\
\text { welding, and is compatible with material to } \\
\text { which it is attached." Sec. 15493, W-030-C2 }\end{array}$ & & sc & $\mathrm{GS}^{*}$ & $\begin{array}{l}\text { CMTRs, COC or dedication needed to certify } \\
\text { the material's allowable strength for the } \\
\text { pipe system design analyses. } \\
\text { * See also discussion on hangers and } \\
\text { supports, Sec. } 3.0 \& 4.0 \text {. }\end{array}$ \\
\hline
\end{tabular}




\begin{tabular}{|c|c|c|c|c|c|}
\hline \multirow{2}{*}{$\begin{array}{l}\text { EQUIPMENT } \\
\text { IDENTIFICATION } \\
\text { NUMBER }\end{array}$} & \multirow{2}{*}{ DESCRIPTION } & \multirow{2}{*}{ SPECIFICATION } & \multicolumn{2}{|c|}{ CLASSIFICATION } & \multirow{2}{*}{ COMMENTS } \\
\hline & & & $\begin{array}{l}\text { Required } \\
\text { per Blo }\end{array}$ & MEETS & \\
\hline 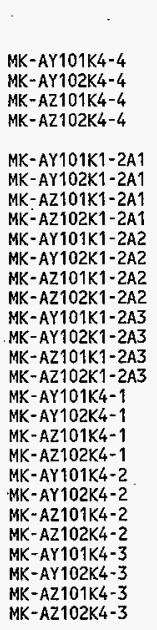 & $\begin{array}{l}\text { Recirc. vent cooling modules, cont'd. } \\
\text { Valving out of tanks (bypass mode). } \\
\text { Butterfly, 8", wafer style, CL } 150 \text { SST body, } \\
\text { stem and disc, bubble tight. With remote } \\
\text { operators. See pipe code M-9, Section } 15493 \text {. } \\
\text { Isolation valving (bypass mode). } \\
\text { Butterfly, 8" \& 10", wafer style, CL } 150 \# \text { SST } \\
\text { body, stem and disc, bubble tight. All with } \\
\text { renote operators. } \\
\text { See pipe code } M-9 \text { of W-030-C2, Section } 15493 \text {. }\end{array}$ & $W-030-c 2$ & sc & $s s^{*}$ & $\begin{array}{l}\text { * See also general discussion on valves, } \\
\text { Sec. } 3.0 \text { \& } 4.0 \text {. } \\
\text { valving meets ss based on confinement. } \\
\text { coc from prime constr. contractor, stating } \\
\text { valve bodies and bonnets, expansion joints } \\
\text { and gaskets comply with the specifications } \\
\text { and drawings, in cVI } \# 22525 \text {, supp. } 113 \text {. } \\
\text { coc from prime constr. contractor for valve } \\
\text { bodies and bonnets in cvI } \$ 22525 \text {, supp. } 113 \text {. }\end{array}$ \\
\hline $\begin{array}{l}\text { RE-AZK1-1 \& } \\
\text { RIAS-AZK1-1 }\end{array}$ & $\begin{array}{l}\text { Stack Monitoring System } \\
\text { Beta/Gamma Radioactive Particulate Monitor } \\
\text { Instr. Loop and CAM Interlock to fans }\end{array}$ & $W-030-P 16$ & sc & ss & $\begin{array}{l}\text { QAP in vendor submittal } 2 . \\
\text { CAM Interlock depends on interface with MCS } \\
\text { to perform safety function; LCU cabinets } \\
\text { and instruments qualified to } \$ S . \\
\text { * See also discussion, Sec. } 3.0 \& 4.0 \text {. }\end{array}$ \\
\hline
\end{tabular}




\begin{tabular}{|c|c|c|c|c|c|}
\hline \multirow{2}{*}{$\begin{array}{l}\text { EQUIPMENT } \\
\text { IDENTIFICATION } \\
\text { NUMBER }\end{array}$} & \multirow{2}{*}{ DESCRIPTION } & \multirow{2}{*}{ SPECIFICATION } & \multicolumn{2}{|c|}{ CLASSIFICATION } & \multirow{2}{*}{ COMMENTS } \\
\hline & & & $\begin{array}{l}\text { Required } \\
\text { per B|0 }\end{array}$ & MEETS & \\
\hline $\begin{array}{l}\text { FE-AZK1-1, } \\
\text { FIT-AZK1-1, } \\
\text { UC-AZK1-2, \& } \\
\text { FAL-AZKI-1A }\end{array}$ & CAM flow Alarm Switch Instr. Loop & & sc & sc & $\begin{array}{l}\text { Procured as part of entire sampling system; } \\
\text { instruments are hardwired and do not depend } \\
\text { on interface with MCS to perform safety } \\
\text { function. }\end{array}$ \\
\hline LCU-1 \& LCU-2 & MCS Instrument Interface Cabinets & WHC-S-4013 & ss & ss & $\begin{array}{l}\text { Assembled cabinets qualified to } S S \text {, incl. } \\
0.12 \mathrm{~g} \text { DBE, based on vendor test report. }\end{array}$ \\
\hline $\begin{array}{l}\text { Wiring } \\
\text { Breakers. }\end{array}$ & $\begin{array}{l}\text { Power Supply - Normal } \\
\text { 600V, Type TC, Hypalon or PVC jacket } \\
500 \mathrm{~A}, 400 \mathrm{~A} \text {, and } 225 \mathrm{~A} \text { trip, UL listed. }\end{array}$ & $\mathrm{W}-030-\mathrm{c} 2$ & sc & $\begin{array}{l}\text { SS* } \\
\text { GS* }\end{array}$ & $\begin{array}{l}\text { * See also discussion of elec. power } \\
\text { supplies, Sec. } 3.0 \& 4.0 \text {. } \\
\text { Power cable dedicated in Design Analysis } \\
\text { W-030-086 with receipt inspection in vendor } \\
\text { submittal } 175 \text { (CGI dedication). }\end{array}$ \\
\hline $\begin{array}{l}\text { Diesel } \\
\text { generator }\end{array}$ & $\frac{\text { Power Supply - Backup }}{125 \mathrm{~kW}}$ & W-030-P11 & sc & ss* & $\begin{array}{l}\text { * See also discussion of elec. power } \\
\text { supplies, Sec. } 3.0 \& 4 \text { \&.0. } \\
\text { Qualified to Ss requirements, see vendor } \\
\text { submittal } 4 \text {. System includes diesel } \\
\text { generator, breakers and ATS }-1 \&-2 \text {. }\end{array}$ \\
\hline Breakers & 600 V, 3 pole, 200A trip, UL listed & & sc & $S S^{*}$ & $\cdot$ \\
\hline $\begin{array}{l}\text { ATS }-1 \\
\text { ATS-2 }\end{array}$ & $480 \mathrm{VAC}, 225 \mathrm{~A}, 3 \mathrm{PH}, 4 \mathrm{~W}$ & & sc & $s s^{*}$ & \\
\hline $\begin{array}{l}\text { UPS-1 } \\
\text { UPS-2 } \\
\text { UPS-3 }\end{array}$ & $8 \mathrm{~kW} / 10 \mathrm{KVA}$ Rating & $W-030-P 17$ & sc & ss* & $\begin{array}{l}\text { UPSs dedicated for ss use in Design } \\
\text { Analysis } \$-030-89 \text {. See cVI } \# 22525 \text {, } \\
\text { Supp. 16. }\end{array}$ \\
\hline Wiring & 600V, Type TC, Hypalon or PVC jacket & $\mathrm{W}-030-\mathrm{C} 2$ & sc & ss* $^{*}$ & GGI Dedication for wire in $\mathrm{w}-030-86, \mathrm{w} /$ \\
\hline ÄS-3 & $480 \mathrm{VAC}, 60 \mathrm{~A}, 3 \mathrm{PH}, 3 \mathrm{~W}, \mathrm{UL}$ listed & $W-030-c 2$ & sc & $\mathrm{SS}^{\star}$ & \\
\hline Supply Tank & 300 gat capacity with secondary containment. & $W-030-P 24$ & sc & $s s^{*}$ & $\begin{array}{l}\text { CMTRs and design analyses for tank in } \\
\text { CVI } \# 22525 \text {, supp. } 34 \text {. }\end{array}$ \\
\hline
\end{tabular}




\section{DISTRIBUTION SHEET}

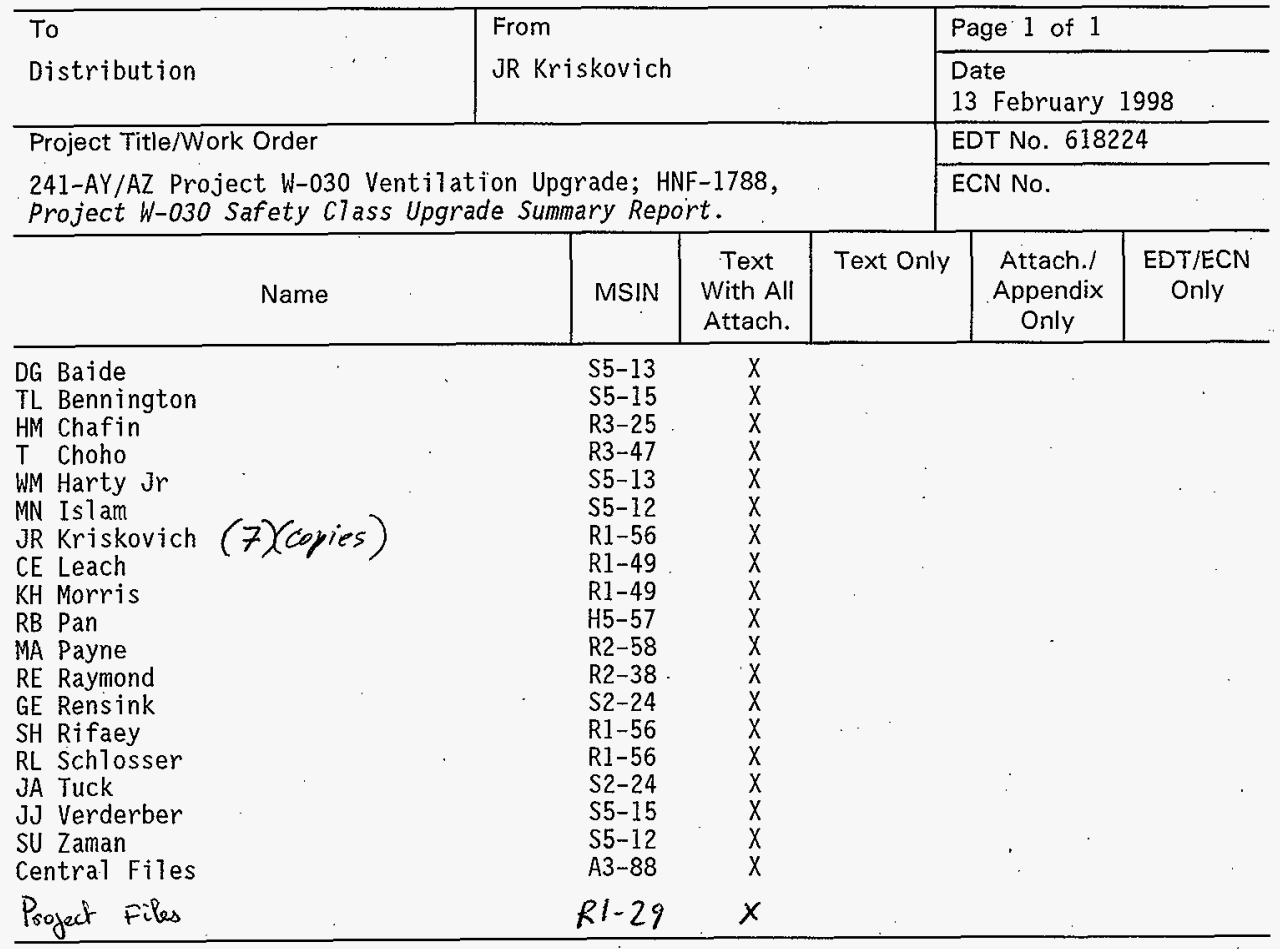

